\title{
Short-Term Depression of Sprouted Mossy Fiber Synapses from Adult-Born Granule Cells
}

\author{
ㄴ.William D. Hendricks, ${ }^{1,3}$ Yang Chen, ${ }^{2}$ AeSoon L. Bensen, ${ }^{2}$-Gary L. Westbrook, ${ }^{2}$ and ${ }^{\circledR E}$ Eric Schnell ${ }^{3,4}$ \\ ${ }^{1}$ Neuroscience Graduate Program, ${ }^{2}$ Vollum Institute, and ${ }^{3}$ Department of Anesthesiology and Perioperative Medicine, Oregon Health \& Science University, \\ Portland, Oregon 97239, and ${ }^{4}$ VA Portland Health Care System, Portland, Oregon 97239
}

Epileptic seizures potently modulate hippocampal adult neurogenesis, and adult-born dentate granule cells contribute to the pathologic retrograde sprouting of mossy fiber axons, both hallmarks of temporal lobe epilepsy. The characteristics of these sprouted synapses, however, have been largely unexplored, and the specific contribution of adult-born granule cells to functional mossy fiber sprouting is unknown, primarily due to technical barriers in isolating sprouted mossy fiber synapses for analysis. Here, we used $D c x C r e E R^{T 2}$ transgenic mice to permanently pulse-label age-defined cohorts of granule cells born either before or after pilocarpine-induced status epilepticus (SE). Using optogenetics, we demonstrate that adult-born granule cells born before SE form functional recurrent monosynaptic excitatory connections with other granule cells. Surprisingly, however, although healthy mossy fiber synapses in CA3 are well characterized "detonator" synapses that potently drive postsynaptic cell firing through their profound frequency-dependent facilitation, sprouted mossy fiber synapses from adult-born cells exhibited profound frequency-dependent depression, despite possessing some of the morphological hallmarks of mossy fiber terminals. Mature granule cells also contributed to functional mossy fiber sprouting, but exhibited less synaptic depression. Interestingly, granule cells born shortly after SE did not form functional excitatory synapses, despite robust sprouting. Our results suggest that, although sprouted mossy fibers form recurrent excitatory circuits with some of the morphological characteristics of typical mossy fiber terminals, the functional characteristics of sprouted synapses would limit the contribution of adult-born granule cells to hippocampal hyperexcitability in the epileptic hippocampus.

Key words: adult neurogenesis; dentate; epilepsy; mossy fiber; seizure; sprouting

\section{Significance Statement}

In the hippocampal dentate gyrus, seizures drive retrograde sprouting of granule cell mossy fiber axons. We directly activated sprouted mossy fiber synapses from adult-born granule cells to study their synaptic properties. We reveal that sprouted synapses from adult-born granule cells have a diminished ability to sustain recurrent excitation in the epileptic hippocampus, which raises questions about the role of sprouting and adult neurogenesis in sustaining seizure-like activity.

\section{Introduction}

Repeated seizures lead to epilepsy through the process of epileptogenesis, which likely results from alterations in neural circuits

\footnotetext{
Received March 17, 2017; revised April 25, 2017; accepted May 3, 2017.

Author contributions: W.D.H., G.L.W., and E.S. designed research; W.D.H., Y.C., A.L.B., and E.S. performed research;G.L.W. and E.S. contributed unpublished reagents/analytictools; W.D.H., Y.C., and E.S. analyzed data;W.D.H. and E.S. wrote the paper.

This work was funded by Department of Veterans Affairs, Veterans Health Administration, Office of Research and Development, Biomedical Laboratory Research and Development CDA-2 award 005-10S (E.S.); Department of Veterans Affairs Merit Review Award 101-BX002949 (E.S.); National Institutes of Health (NIH) Grant F31-NS098597 (W.D.H.); NIH Grant R01-NS080979 (G.L.W.) the Ellison Medical Foundation (G.L.W.); and NIH P30-NS061800 (Oregon Health \& Science University Imaging Center) awards. We thank Drs. Zhi-Qi Xiong and Xuewen Cheng (Shanghai Institute for Neuroscience) for graciously providing the DcxCreER ${ }^{T 2}$ mouse line, and members of the Schnell and Westbrook Laboratories for critical feedback and discussion on the manuscript.

The authors declare no competing financial interests.

Correspondence should be addressed to Eric Schnell, MD, PhD, 3710 SW US Veterans Hospital Road, P3ANES, Portland, 0R 97239. E-mail: schneler@ohsu.edu.
}

(Chang and Lowenstein, 2003). However, it is unclear how network alterations in the brain contribute to circuit hyperexcitability. Temporal lobe epilepsy is associated with dramatic morphological changes to the hippocampus, including death of CA1 and CA3 pyramidal neurons (Babb et al., 1984; DeGiorgio et al., 1992), loss of interneurons (Sloviter, 1987; Doherty and Dingledine, 2001), and the aberrant growth of dentate granule cell dendrites and axons (Nadler et al., 1980; Ribak et al., 2000).

The sprouting of mossy fiber axons away from their normal targets in the hilus and CA 3 and into the inner molecular layer of the dentate gyrus has long been particularly intriguing. After sprouting, these axons contact the dendrites of other granule cells, forming a connection that is largely, if not entirely, absent in healthy animals (Tauck and Nadler, 1985; Sutula et al., 1988; 
Okazaki et al., 1995; Buckmaster et al., 2002). Mossy fibers in region CA3 produce large unitary EPSCs that profoundly facilitate glutamate release during repetitive activation and have been designated as "detonator synapses" due to their ability to potently drive postsynaptic cell spiking (Salin et al., 1996; Sachidhanandam et al., 2009; Vyleta et al., 2016). Thus, sprouted fibers with the same characteristics could conceivably form strong recurrent excitatory feedback loops and drive seizure generation.

Mossy fibers originate from mature dentate granule cells, but the hippocampal circuit is constantly refined by ongoing postnatal neurogenesis (van Praag et al., 2002). Interestingly, seizures increase the generation of new granule cells (Parent et al., 1997, 2006; Jessberger et al., 2005, 2007), which integrate into local circuitry (Bengzon et al., 1997; Parent et al., 1997, 2006; OverstreetWadiche et al., 2006; Jessberger et al., 2007; Kron et al., 2010) and contribute to mossy fiber sprouting (Jessberger et al., 2007; Kron et al., 2010; Althaus et al., 2016). The low connection probability between any one adult-born granule cell and its potential postsynaptic targets, as well as the challenges of definitively isolating fibers derived from adult-born granule cells, has limited direct assessment of adult-born cells in epileptic brains. Thus, despite the evidence that adult-born granule cells contribute to mossy fiber sprouting, the functional properties of these sprouted synapses are still not known.

Here we isolated cohorts of age-defined granule cells using genetically modified mice to examine the contribution of adultborn granule cells to mossy fiber sprouting, and to determine the functional properties of sprouted mossy fiber synapses. Despite similar structural characteristics, sprouted mossy fiber synapses had distinct functional properties from mossy fiber-CA3 synapses, most notably a profound frequency-dependent synaptic depression, which was most prominent in synapses emanating from adult-born dentate granule cells. Additionally, granule cells born after seizures did not appear to make functional excitatory synapses with other granule cells, despite the morphological identification of boutons in the inner molecular layer (IML).

\section{Materials and Methods}

Animals. Homozygous doublecortin-CreER ${ }^{T 2}$ transgenic mice (line F18, generously supplied by Drs. Xuewen Cheng and Zhi-Qi Xiong; Cheng et al., 2011; RRID:MGI:5438982) were maintained on a C56Bl6/J background and crossed with either homozygous Gt(ROSA)26Sor ${ }^{\text {tm9(CAG-tdTomato)Hze }}$ (Ai9;

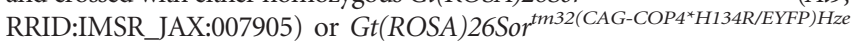
(Ai32; RRID:IMSR_JAX:012569) Cre-reporter lines for imaging and physiology experiments, respectively. Cre-mediated recombination was induced by administration of tamoxifen (TAM). To label newborn granule cells in adult mice, TAM $(40 \mathrm{mg} / \mathrm{kg}$ in corn oil, i.p.) was administered twice daily for $5 \mathrm{~d}$. Neonatally born granule cells were labeled with two injections of TAM $(20 \mathrm{mg} / \mathrm{kg}$ in corn oil, i.p.) $12 \mathrm{~h}$ apart on postnatal day (P) 6. Veterinary care was provided by Oregon Health \& Science University's Department of Comparative Medicine in a vivarium accredited by the Association for Assessment and Accreditation of Laboratory Animal Care, and all experiments and animal care were performed in accordance with state and federal guidelines and protocols approved by the institutional animal care and use committee.

Seizure induction. Two-month-old male mice were pretreated with an intraperitoneal injection of $1 \mathrm{mg} / \mathrm{kg}$ scopolamine methyl bromide (SigmaAldrich) to block the peripheral cholinergic effects of pilocarpine. Twenty minutes later, mice were treated with $325 \mathrm{mg} / \mathrm{kg}$ pilocarpine, injected intraperitoneally (Cayman Chemicals), to induce seizures. Animals were continuously monitored and seizures were graded on a modified Racine scale (Shibley and Smith, 2002). Status epilepticus (SE) was defined by a state of continuous Grade 2 seizures following $\geq 3$ Grade $3-5$ seizures. Following $2 \mathrm{~h}$ of continuous SE, animals were given $10 \mathrm{mg} / \mathrm{kg}$ diazepam (Sigma-Aldrich) to terminate seizures. Mice were given soft food and intraperitoneal injections of $1 \mathrm{ml}$ of $5 \%$ glucose in $0.45 \%$ normal saline every $12 \mathrm{~h}$ until normal activity resumed. Mice that did not develop SE were humanely killed; noninjected littermates were used as controls. Although not quantified, mice treated with pilocarpine were noted to have spontaneous seizures in the months following acute SE.

Immunofluorescence. Four-month-old mice were deeply anesthetized by inhalation of $4 \%$ isoflurane followed by injection of $1 \mathrm{ml}$ of $1.2 \%$ avertin (Sigma-Aldrich), and transcardially perfused with $5 \mathrm{ml}$ of PBS followed by $20 \mathrm{ml}$ of $4 \%$ paraformaldehyde-PBS (PFA-PBS). Mice were then decapitated, and brains were removed and postfixed overnight in $4 \%$ PFA-PBS. Fifty micrometer coronal sections were cut using a Leica VT1000S microtome and stored in PBS. Sections were permeabilized and blocked with $0.4 \%$ Triton-PBS containing $10 \%$ normal goat serum (NGS) for $90 \mathrm{~min}$ at room temperature. For BrdU birth-dating experiments, slices were permeabilized by incubation in $\mathrm{K}^{+}$-containing PBST (K-PBST) for $45 \mathrm{~min}$, followed by $2 \mathrm{~N} \mathrm{HCl} \mathrm{K-PBST} \mathrm{for} 30 \mathrm{~min}$ at $37^{\circ} \mathrm{C}$. Following $3 \times 15$ min washes in PBST, slices were incubated in PBST with 1.5\% NGS and varying combinations of the following: 1:500 guineapig anti-ZnT3 (Synaptic Systems, catalog \#197 004, RRID:AB_2189667), 1:500 rabbit anti-DsRed (Clontech Laboratories, catalog \#632496, RRID: AB_10013483), 1:500 mouse anti-GAD67 (Millipore, catalog \#MAB5406, RRID:AB_2278725), rat anti-BrdU (Abcam, catalog \#AB6326, RRID: AB_305426), 1:400 guinea-pig anti-doublecortin (Millipore, catalog \#AB2253, RRID:AB_1586992), or 1:400 rabbit anti-GFP Alexa Fluor 488 conjugate (Invitrogen, catalog \#A-21311, RRID:AB_221477). Following overnight $(18-24 \mathrm{~h})$ incubations at $4^{\circ} \mathrm{C}$, slices were washed in PBST and incubated with secondary antibodies goat anti-guinea-pig Alexa Fluor 488, goat anti-rabbit Alexa Fluor 568, and goat anti-mouse Alexa Fluor 647 (Life Sciences) at 1:500, overnight at $4^{\circ} \mathrm{C}$. Slices were then briefly washed in standard PBS, postfixed in $4 \%$ PFA for $20 \mathrm{~min}$, counterstained with 1:30,000 DAPI, and mounted onto slides with CMFR2 highrefractive index mounting media (Citifluor).

Standard confocal images were acquired from sections of the dorsal hippocampus of perfusion-fixed DcxCre:: $t d T$ mice using a Zeiss LSM 780 with a $40 \times / 1.4$ numerical aperture oil objective; super-resolution images were acquired on a Zeiss LSM 710 equipped with an AiryScan detector and $63 \times / 1.4$ numerical aperture oil objective. For bouton-counting experiments, $20 \mu \mathrm{m}$ vertical $z$-stacks were captured at a $1024 \times 1024$ pixel density with $0.38 \mu \mathrm{m}$ step width. Linear adjustments (brightness, contrast, and intensity) were applied to the whole image in ImageJ/FIJI (National Institutes of Health) to aid in counting, and kept constant across samples. For each animal, the central portion of the suprapyramidal blade of the dentate gyrus in four separate hippocampal sections was imaged to include both the full GCL and IML cross section as well as portions of the middle molecular layer and hilus. Only boutons that distinctly colocalized with ZnT3 on all three imaging planes were counted as mossy fiber boutons in the IML. tdTomato-positive cell bodies were counted if they were fully located within the GCL of these images, as delineated with DAPI. IML volume was calculated from threedimensional (3D) renders and bouton volume measurements were conducted using the surface render and analysis suite in Imaris (Bitplane). Filopodia were manually identified from $3 \mathrm{D}$ renders as $>1$ $\mu \mathrm{m}$ protrusion from the main bouton not connected to longer axonal fibers. Bouton measurements and tdT + bouton density quantification was performed by an experimenter blind to experimental group assignment.

Slice preparation and physiological recordings. Four-month-old DcxCre::ChR2 mice used for ex vivo electrophysiology experiments were deeply anesthetized with isoflurane and avertin as described above, and transcardially perfused with ice-cold choline-based or $N$-methyl-Dglucamine (NMDG)-based solution, as during the course of this work we found better cell preservation in slices prepared from NMDG-perfused animals (Ting et al., 2014). We otherwise did not find any electrophysiologic differences that resulted from a change in perfusion solution. Choline-based solution contained the following (in $\mathrm{mm}$ ): 110 choline $\mathrm{Cl}$, $25 \mathrm{NaHCO}_{3}, 10$ glucose, $7 \mathrm{MgCl}_{2}, 3 \mathrm{Na}$-pyruvate, $2.4 \mathrm{KCl}, 1.3 \mathrm{Na}-$ ascorbate, $1.25 \mathrm{NaH}_{2} \mathrm{PO}_{4}{ }^{\star} 2 \mathrm{H}_{2} \mathrm{O}$, and $0.5 \mathrm{CaCl}_{2}$. NMDG-based solution contained the following (in mM): $93 \mathrm{NMDG}, 30 \mathrm{NaHCO}_{3}, 24$ glucose, 20 HEPES, $5 \mathrm{Na}$-ascorbate, $5 \mathrm{~N}$-acetyl cysteine, $3 \mathrm{Na}$-pyruvate, $2.5 \mathrm{KCl}, 2$ 
thiourea, $1.2 \mathrm{NaH}_{2} \mathrm{PO}_{4}, 10 \mathrm{MgSO}_{4}$, and $0.5 \mathrm{CaCl}_{2}$. Mice were then rapidly decapitated, the hippocampus was dissected, and $300 \mu \mathrm{m}$ transverse hippocampal sections were prepared in ice-cold perfusion solution using a Leica VT1200S vibratome. For CA3 recordings, hippocampal dissection was omitted and brains were cut into $300 \mu \mathrm{m}$ sagittal sections to preserve CA3 pyramidal cells and mossy fiber axons. After choline-based preparation, slices were allowed to recover in warm ACSF for $30 \mathrm{~min}$ followed by an additional $30 \mathrm{~min}$ at room temperature before recordings. After NMDG-based preparation, sections were allowed to recover in warm NMDG-based cut solution for $15 \mathrm{~min}$, followed by an additional 45 min recovery in standard ACSF at room temperature.

Electrophysiological recordings were made with $3-5 \mathrm{M} \Omega$ borosilicate glass pipettes filled with the following $\mathrm{Cs}^{+}$-based internal solution (in mM): 113 Cs-gluconate, $17.5 \mathrm{CsCl}, 10 \mathrm{HEPES}, 10 \mathrm{EGTA}, 8 \mathrm{NaCl}, 2 \mathrm{Mg}$ ATP, 0.3 Na-GTP, 0.05 Alexa Fluor 568, pH 7.3, adjusted with $\mathrm{CsOH}$ (osmolarity adjusted to $295 \mathrm{mOsm}$ ). For voltage-clamp experiments, QX-314-Cl (5 mM; Tocris Bioscience) was included in the internal solution to block unclamped action potentials. Pipettes were wrapped with Parafilm to minimize pipette capacitance. Granule cells were identified and patched using live infrared differential interference contrast microscopy, after a lack of ChR2-YFP expression in a particular cell was confirmed using fluorescence microscopy. High-resistance seals (>5G $\Omega$ ) were made and whole-cell recordings were obtained by applying brief suction. A hyperpolarizing $(-10 \mathrm{mV})$ voltage step was applied before each sweep and used to monitor series resistance, input resistance, and cell capacitance. Series resistance was not compensated; cells with a $>30 \%$ change in series resistance during experiments were excluded from analysis. All cells were filled with $50 \mu \mathrm{M}$ Alexa Fluor 568 to confirm granule cell identity and to verify the absence of hilar basal dendrites. For optogenetic stimulation, blue $\left(1 \mathrm{~ms}, 470 \mathrm{~nm}, 8 \mathrm{~mW} / \mathrm{mm}^{2}\right)$ light was delivered through a $40 \times$ water immersion objective at $20 \mathrm{~s}$ intervals, powered by an LED (ThorLabs), targeted at the inner molecular layer (for granule cell recordings) or stratum lucidum (for CA3 recordings). All experiments were performed in the presence of the $\mathrm{GABA}_{\mathrm{A}}$-receptor blocker SR95531 (10 $\mu \mathrm{M}$; Ascent) to isolate excitatory currents and to avoid possible contamination of responses by feedforward inhibition or any off-target labeling of interneurons. Stimulation frequency was adjusted for frequency facilitation and paired-pulse facilitation experiments as stated in the text. For some CA3 recordings, electrical stimulation of mossy fiber axons in CA3 was accomplished using a constant voltage stimulator (Digitimer) and a bipolar electrode (FHC) placed in the stratum lucidum. Signals were amplified with an AxoClamp 200B (Molecular Devices) amplifier, low-pass Bessel-filtered at $5 \mathrm{kHz}$, sampled at $10 \mathrm{kHz}$, and digitized with a National Instruments analog-to-digital board. Data were captured with a custom script in Igor Pro 6 (Wavemetrics) for on-line and off-line analysis and further statistical analysis. For presentation, off-line filtering was accomplished with a $2 \mathrm{kHz}$ Gaussian filter. Cells were voltage-clamped to $-70 \mathrm{mV}$ for AMPAR-mediated response analysis, and to $+40 \mathrm{mV}$ to unmask NMDAR-mediated responses. AMPAR/NMDAR ratios were determined by measuring the peak current in voltage clamp at $-70 \mathrm{mV}$ for the AMPAR component and the remaining current at $60 \mathrm{~ms}$ poststimulus at $+40 \mathrm{mV}$ for the NMDAR component. Evoked responses were included if maximal current amplitude was $>5 \mathrm{pA}$ within $20 \mathrm{~ms}$ of stimulus. The following drugs were included in the ACSF when indicated: NBQX (10 $\mu \mathrm{M}$; Ascent), SR95531 (10 $\mu \mathrm{M}$; Ascent), DCG-IV [(2S,2'R)-2-(2'-dicarboxycyclopropyl) glycine; $1 \mu \mathrm{M}$; Tocris Bioscience]. The liquid junction potential was $8 \mathrm{mV}$ and was uncorrected.

Experimental design and statistical analysis. Statistical analysis was performed in Igor Pro 6 (Wavemetrics) and data are presented as mean \pm SEM unless otherwise noted. $T$ tests were performed on continuous data containing two independent datasets. Experiments with $\geq 3$ datasets were compared with one-way ANOVA with post hoc Dunnett's test when compared with a control (see Fig. 2), or Tukey's test between groups (see Fig. 8). Fischer's exact test was used to compare categorical data of two groups. Unless otherwise noted, data followed a binomial distribution and parametric tests were performed. For all experiments, significance was determined at $p<0.05$.

\section{Results}

\section{Faithful pulse labeling of temporally distinct dentate granule} cell cohorts

To analyze the structure and synaptic function of sprouted mossy fibers from neonatally derived and adult-born dentate granule cells, we used transgenic Dcx-CreER ${ }^{T 2}$ mice (Cheng et al., 2011) to pulse-label discrete, temporally defined cohorts of immature granule cells. Crossed DcxCreER ${ }^{T 2}:: G t(R O S A) 26 S_{\text {r }}^{\text {tm } 9(C A G-t d T o m a t o) H z e}$ (Ai9) mice (henceforth referred to as DcxCre::tdT mice) were given intraperitoneal injections of TAM to initiate Credependent tdTomato expression in immature granule cells. These cells continue to express tdTomato after their maturation (Fig. 1A-E). BrdU colabeling (Fig. 1B) demonstrated that labeled cells were born during a 2 week window before TAM administration, consistent with the normal expression pattern of doublecortin, which is high for the first 2-3 weeks after granule cell mitosis (Brown et al., 2003). Labeling efficiency of granule cells born during this 2 week window was $\sim 40 \%$, with negligible labeling of cells born even 1 week earlier or later (data not shown). Similar results were obtained with $D c x C r e E R^{T 2}:$ : Gt(ROSA) 26Sor ${ }^{\left.\text {tm 32(CAG-COP4 }{ }^{*} H 134 R / E Y F P\right) H z e}$ (Ai32) mice (Fig. 1F; henceforth referred to as DcxCre::ChR2).

Importantly, cell labeling in $D c x C r e E R^{T 2}$ mice occurs after neuronal differentiation, such that following removal of TAM, pulse-labeled cells continue to express reporter proteins while subsequently born dentate granule cells are not labeled. Adultborn cells were never labeled in animals that had received neonatal TAM, as assessed by doublecortin (Dcx) costaining (data not shown) or with BrdU injections in adults $(0.0 \%$ of adult-born BrdU+ cells labeled with ChR2-YFP in DcxCre::ChR2 mice, $n=$ 0/137 cells, 3 mice; Villasana et al., 2015). Although all granule cell labeling was restricted to temporally isolated cohorts, in some animals we observed labeling of a few GAD + interneurons in the hilus, CA1, and CA3, as determined by GAD costaining, cell location, and morphology, in both epileptic and control mice, as previously observed (Cheng et al., 2011; Fig. 1C,D, stratum radiatum of region CA3).

To examine mossy fiber synaptic function, we used optogenetics to activate pulse-labeled granule cell cohorts in DcxCre:: ChR2 mice (Fig. 1G-J). Short (1 ms) pulses of $470 \mathrm{~nm}$ blue light $\left(8 \mathrm{~mW} / \mathrm{cm}^{2}\right)$ reliably produced photocurrents (Fig. $\left.1 G\right)$ and action potential firing (Fig. $1 H$ ) in ChR2-expressing granule cells. $\mathrm{ChR} 2+$ granule cells demonstrated robust spike fidelity during 1 $\mathrm{Hz}$ LED illumination (fidelity during a 50-pulse train: $96.1 \pm$ $1.2 \%, n=8$ cells), but spike failures became evident during longer-duration trains at higher frequencies $(>15$ pulses at 20 $\mathrm{Hz}$, data not shown). Photostimulation of CA3 stratum lucidum in hippocampal slices from labeled DcxCre::ChR2 animals evoked mossy fiber EPSCs in CA3 pyramidal cells, which were blocked by the Group II mGluR agonist DCG-IV, as is typical for electrically evoked mossy fiber EPSCs (Fig. $1 I, J$ ).

\section{Adult-born granule cells sprout mossy fiber boutons after pilocarpine-induced seizures}

Retroviral labeling techniques have demonstrated that adultborn granule cells contribute to mossy fiber sprouting after seizures (Jessberger et al., 2007; Kron et al., 2010; Althaus et al., 2016); however, their functionality remains unclear (Walter et al., 2007; Althaus et al., 2016). To determine how immature adult-born granule cells respond to pilocarpine-induced SE evoked at P60, we administered TAM to DcxCre::tdT mice 1 week before SE so that the labeled cohort of adult-born granule cells was 1-3 weeks postmitosis during SE. Mice were examined 2 
A

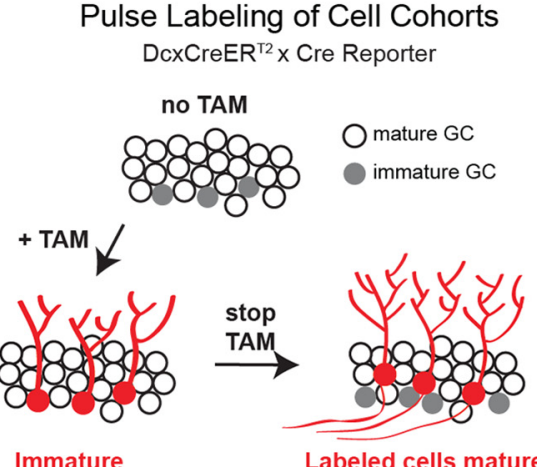

Dcx+ GC labeled

B

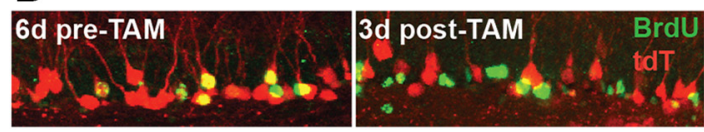

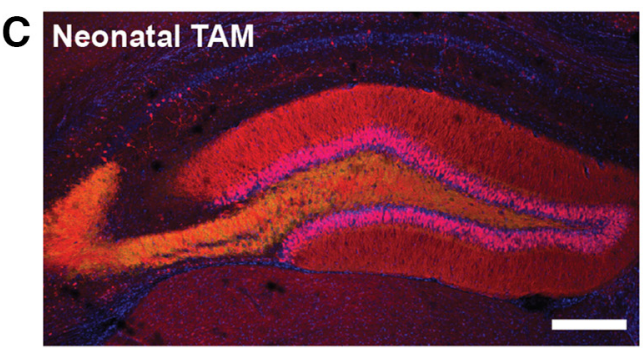

D Adult TAM

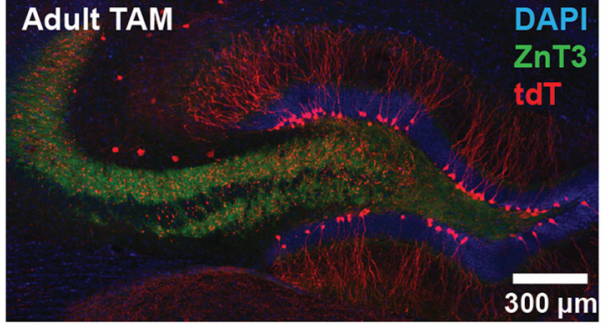

E DCX
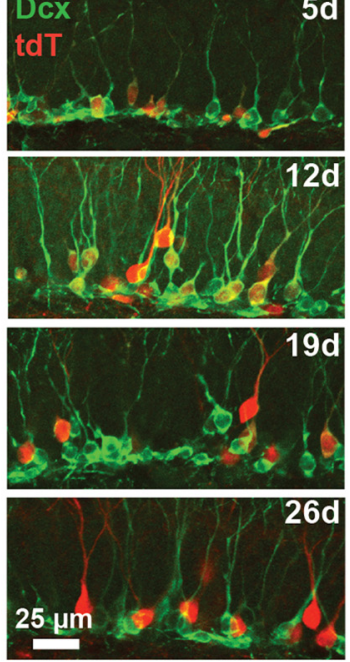

F

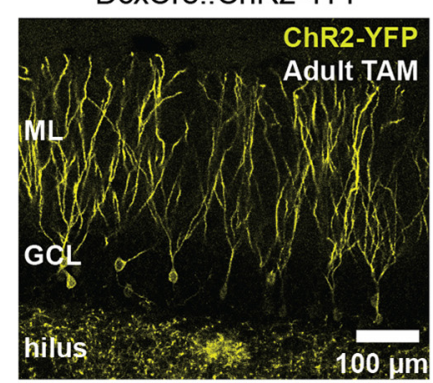

G

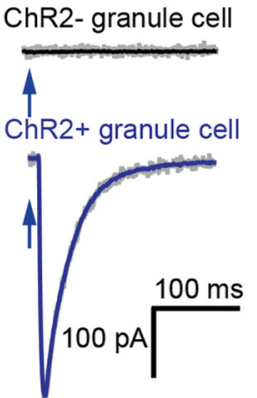

H

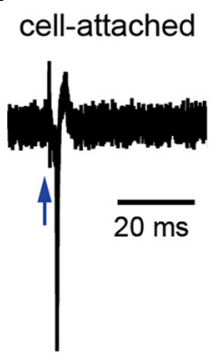

I

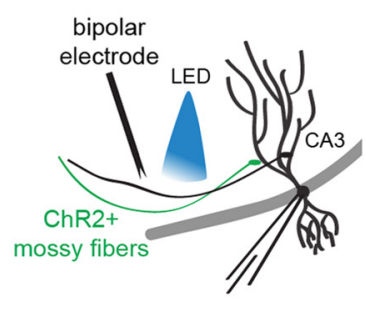

J

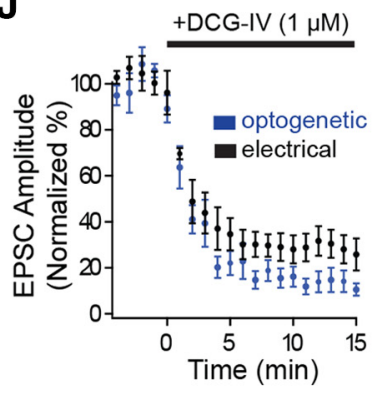

Figure 1. Transgenic pulse labeling of granule cell cohorts. $A$, Approach used to pulse-label temporally defined cohorts of dentate granule cells in DcxCreER ${ }^{T 2}$ transgenic mice. In the absence of TAM, reporter genes are not expressed. TAM administration causes genetic recombination and marker gene expression (red) in immature neurons (gray), which persists after these cells mature. Cells born after TAM administration are not labeled. $\boldsymbol{B}$, BrdU/tdTomato (tdT) colabeling in DcxCre::tdT mice. Mice were given BrdU injections to label mitotic cells at different time points relative to TAM injections. Cells born before TAM injection (BrdU $6 \mathrm{~d}$ pre-TAM) colabel with tdT. Cells born after TAM injection (BrdU $3 \mathrm{~d}$ post-TAM) are not colabeled. C, Neonatal (P6) TAM administration broadly labels mature dentate granule cells and mossy fiber axons in the adult (P120) DcxCre::tdTomato mouse (tdT; red). Mossy fiber terminals are labeled with ZnT3 (green) and nuclei with DAPI (blue). $D$, Adult-born granule cells are permanently labeled when TAM is administered to adult $D c x C r e:: t d T$ mice. Image is from a mouse that received TAM at 2 months of age, and was imaged at 4 months of age. $\boldsymbol{E}$, TAM was administered to adult $D c x C r e:: t d T$ mice, and brains were fixed and stained at varying time intervals thereafter. At early time points (5-12 d post-TAM), tdTomato-marked cells (tdT; red) are immature, and colabel with the immature neuronal marker Dcx (green). By $26 \mathrm{~d}$ post-TAM, costaining of tdT + cells with the immature marker Dcx completely disappears, and tdT + cells assume a mature morphology, indicating that pulse-labeled cells have matured and that no younger cells were labeled. $F$, DcxCre::ChR2 mice express ChR2-YFP in dentate granule cell dendrites, somata, and mossy fiber axons following TAM administration. A $20 \times$ confocal stack image of endogenous ChR2-YFP signal in the dentate granule cell layer from a 4-month-old animal given TAM at 2 months. ML, Molecular layers; GCL: granule cell layer. G, LED stimulation (blue arrows; $1 \mathrm{~ms}, 8 \mathrm{~mW} / \mathrm{cm}^{2}$ ) reliably evokes photocurrents in ChR+ granule cells (bottom, blue), but not adjacent $\mathrm{ChR}$ - granule cells (top, black) in healthy mice during whole-cell voltage-clamp recordings. Average traces are overlaid onto 10 individual sweeps (gray). $\boldsymbol{H}$, Reliable spiking of granule cells after LED stimulation (blue arrows) is observed in cell-attached mode. Ten consecutive sweeps are overlaid. I, Experimental design for alternating optogenetic and electrical stimulation of mossy fiber-CA3 pyramidal cell synapses in DcxCre::ChR2 mice. Whole-cell recordings were obtained from CA3 pyramidal cells in 4-month-old mice, while stimulating mossy fibers electrically or optogenetically in the stratum lucidum. TAM was given neonatally to label mossy fiber axons. J, Time course of EPSC inhibition by bath application of DCG-IV. Mossy fiber EPSCs elicited by LED or bipolar electrode stimulation in the stratum lucidum follow similar time course of blockade upon wash-in of $1 \mu \mathrm{M} \mathrm{DCG-IV} \mathrm{(percentage} \mathrm{EPSC} \mathrm{amplitude} \mathrm{of} \mathrm{baseline} \mathrm{following} 15$ min drug wash-in, electrical stimulation: $n=5$; optogenetic stimulation: $n=8, t_{(5.99)}=1.89, p=0.11$, unpaired $t$ test). Data represented as average \pm SEM.

months later, when mossy fiber sprouting becomes well established with this model (Fig. 2A; Cavalheiro et al., 1996). To identify sprouted mossy fiber boutons in the IML of the dentate, we stained tissue with antibodies against zinc transporter 3 (ZnT3), a vesicular transporter protein highly enriched in mossy fiber terminals.

Despite sparse tdT + granule cells in adult-labeled mice, there were abundant tdT + /ZnT3 + boutons in the IML of DcxCre:: tdT mice after SE (Fig. 2B), indicating that granule cells born just before SE robustly contributed to mossy fiber sprouting, which is consistent with prior reports (Jessberger et al., 2007; Kron et al., 2010; Althaus et al., 2016). As expected, healthy control animals had abundant tdT $+/$ ZnT3 + boutons in the hilus and CA3, but had no mossy fiber sprouting, evidenced by the lack of ZnT3 staining or tdT + boutons in the IML (Figs. 1D, 2A, top). Super- resolution confocal images of adult-born mossy fiber boutons (Fig. 2C) were rendered and measured in 3D (Fig. 2D), revealing that seizures altered mossy fiber bouton morphology. Mossy fiber boutons in region CA3 had larger volumes in epileptic mice (Fig. 2E) than CA3 mossy fiber boutons in control (healthy) mice after SE, whereas their sprouted counterparts in the IML were smaller (Fig. 2E). The surface area of sprouted boutons was also reduced (Fig. 2F). Mossy fiber terminals in healthy CA3 form filopodial extensions that directly contact interneurons (Acsády et al., 1998). Interestingly, sprouted mossy fiber boutons from adult-born granule cells had fewer filopodial extensions than their CA3 counterparts (Fig. $2 G$ ), suggesting that sprouted mossy fiber boutons may predominantly contact excitatory cells, as has previously been described using electron microscopy (Buckmaster et al., 2002). 
A
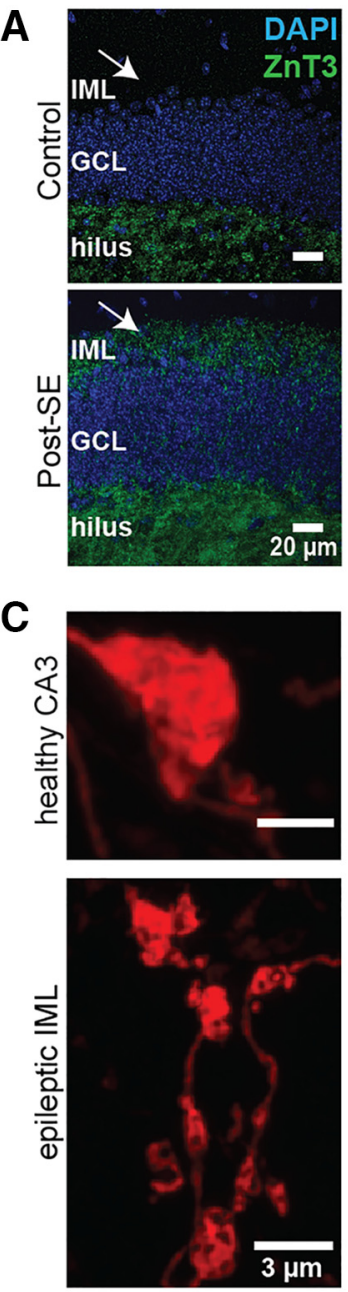

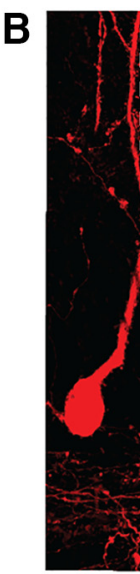

D

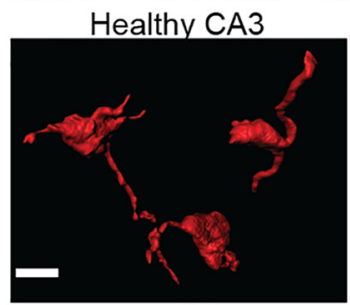

E

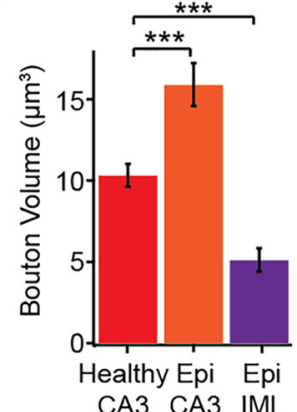

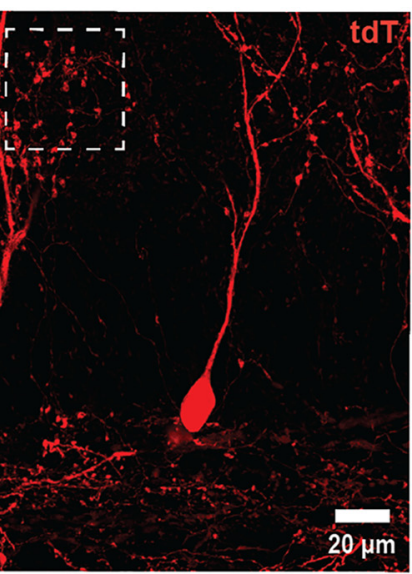

$0 \mu$
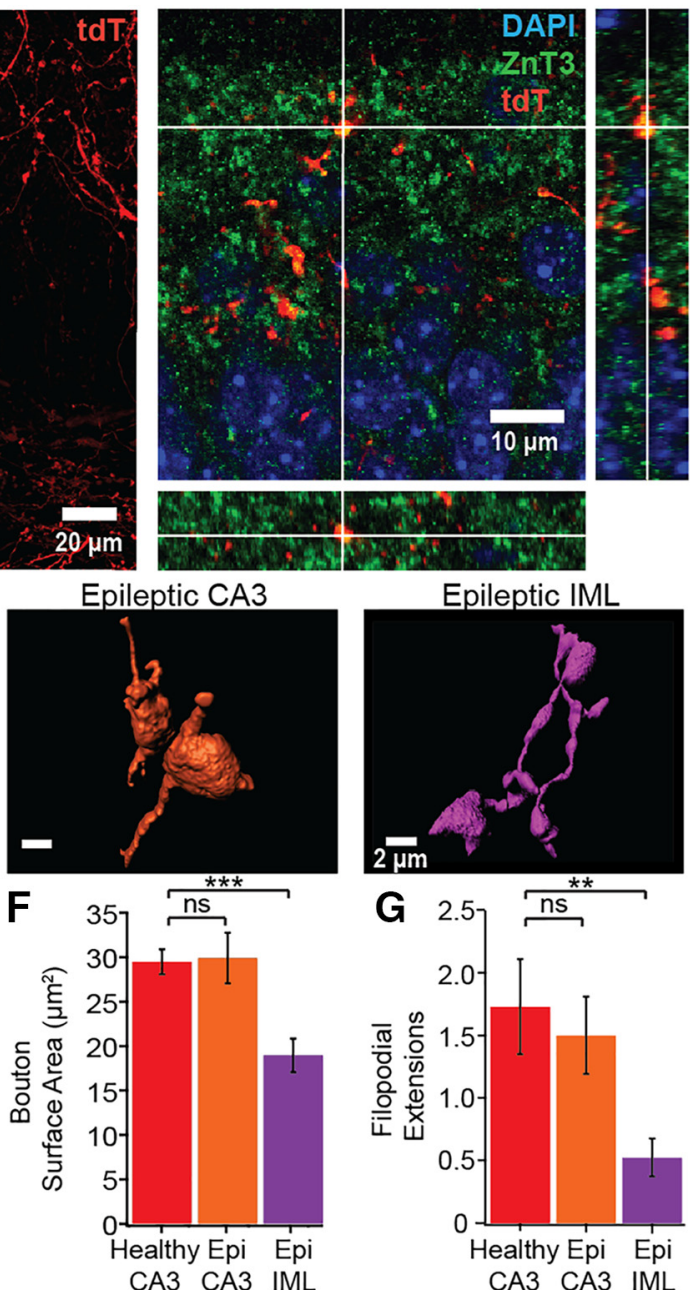

Figure 2. Adult-born granule cells sprout mossy fiber boutons following pilocarpine-induced SE. $\boldsymbol{A}$, Mice treated with pilocarpine to induce SE (bottom), but not control mice (top), have dense mossy fiber sprouting in the IML (arrow) of the dentate gyrus, as measured by ZnT3 immunoreactivity (green). Granule cell nuclei are marked with DAPI (blue). $\boldsymbol{B}$, Representative confocal images from tdT-labeled adult-born granule cells (red) in DcxCre::tdT mice given TAM 1 week before SE demonstrate robust mossy fiber sprouting from these cells. Dashed box indicates corresponding locations from compressed stack image (left) represented in orthogonal single plane projection (right). Mossy fiber terminals are labeled with ZnT3 (green) and nuclei with DAPI (blue). C, Super-resolution images of tdT + boutons from adult-born cells in healthy CA3 (top) and in epileptic mouse IML (bottom). D, 3D rendering of mossy fiber boutons. E, Measurements of mossy fiber bouton volume determined from 3D rendering. Mossy fiber bouton volume is greater in boutons from CA3 in epileptic animals, but sprouted mossy fiber boutons in the IML have decreased volume $\left(F_{(2,81)}=35.0, p<0.0001\right.$, ANOVA; control CA3 vs epileptic CA3, $p=0.0006$; control CA3 vs epileptic IML, $p<0.0001 ; n=21$, 27, 36 boutons for healthy CA3, epileptic CA3, and epileptic IML, respectively; Dunnett's post hoc test, healthy CA3 used as control). $\boldsymbol{F}$, Mossy fiber boutons in epileptic IML have decreased surface area $\left(F_{(2,68)}=10.0, p=0.0002, A N 0 V A ;\right.$ control $C A 3$ vs epileptic CA3, $p=0.99$; control CA3 vs epileptic IML, $p=0.0007 ; n=21,17,33$ boutons for healthy CA3, epileptic CA3, and epileptic IML, respectively; Dunnett's post hoc test, healthy CA3 used as control). $\mathbf{G}$, The average number of filopodia emanating from sprouted mossy fiber boutons is significantly lower than the number of filopodia from boutons in healthy mice $\left(F_{(2,51)}=5.24, p=0.008\right.$, ANOVA; healthy CA3 vs epileptic IML, $p=0.015, n=11,22,21$ boutons for healthy CA3, epileptic CA3, and epileptic IML, respectively; Dunnett's post hoc test, healthy CA3 used as control). All data represented as average \pm SEM. ${ }^{* *} p<0.01,{ }^{* * *} p<0.001$.

\section{Adult-born granule cells drive recurrent excitation via sprouted mossy fibers after SE}

Sprouted mossy fibers are interspersed among other inputs to granule cells and cannot be electrically stimulated as a distinct population, which has limited their functional assessment. By selectively labeling granule cells in DcxCre::ChR2 mice, we were able to optogenetically isolate sprouted mossy fiber inputs and thus directly analyze the function of sprouted synapses originating from adult-born granule cells.

In whole-cell voltage-clamp recordings from post-SE mouse brain slices (Fig. 3A), optogenetic stimulation of adult-born granule cells often evoked EPSCs in ChR2-YFP-negative dentate granule cells ( $n=15$ of 28 cells), whereas these responses were rarely observed in slices from healthy control animals ( $n=2$ of 15 cells; Fig. $3 B, C$ ). These data are consistent with the formation of functional recurrent synapses in epileptic mice (Tauck and $\mathrm{Na}$ - dler, 1985) and minimal granule cell-granule cell connectivity in the dentate gyrus of healthy animals (Ribak and Shapiro, 2007). To determine whether these EPSCs truly reflected the formation of monosynaptic granule cell-granule cell contacts, we blocked polysynaptic activity with NBQX and optogenetically evoked NMDAR-mediated EPSCs at a holding potential of $+40 \mathrm{mV}$. In epileptic mice, monosynaptic NMDAR-mediated EPSCs were present in one-third of granule cells tested ( $n=5$ of 15 ; Fig. $3 D$ ), whereas these responses were not observed in control animals ( $n=0$ of 15 cells). Sprouted mossy fiber responses were strongly inhibited by DCG-IV, similar to LED-evoked mossy fiber-CA3 responses in control animals (Fig. 3E).

Monosynaptic, granule cell-granule cell EPSCs could either originate from aberrantly sprouted mossy fiber synapses in the IML or alternatively from mossy fiber synapses acquired by newly formed hilar basal dendrites (Ribak et al., 2000). To differentiate 
A

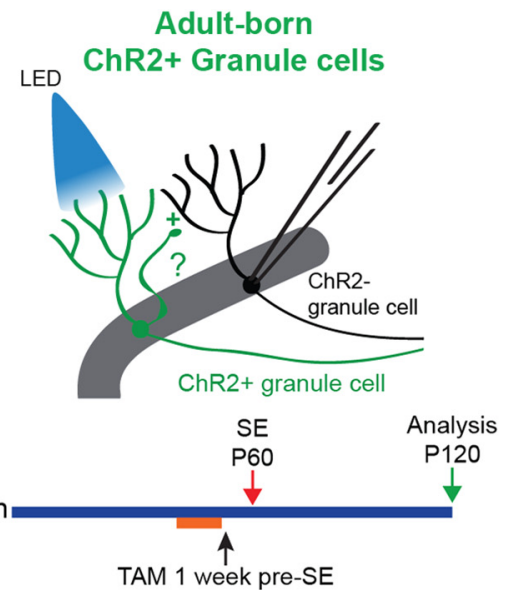

D

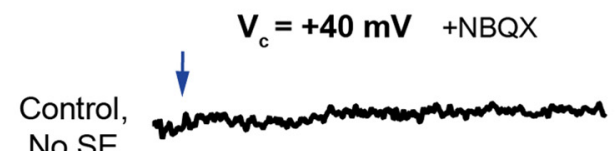

No SE

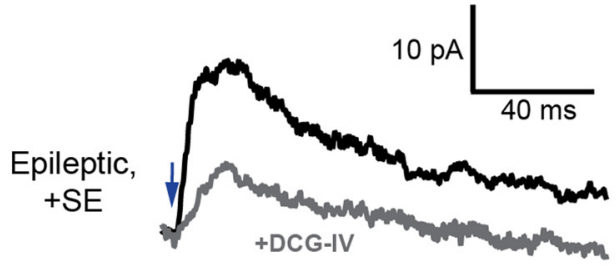

B

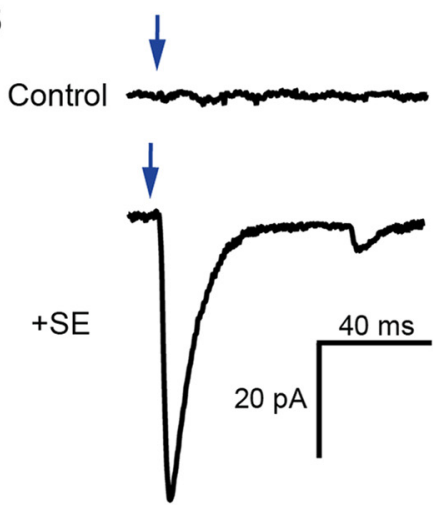

E

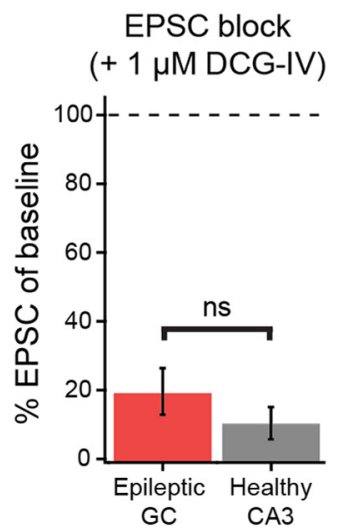

C

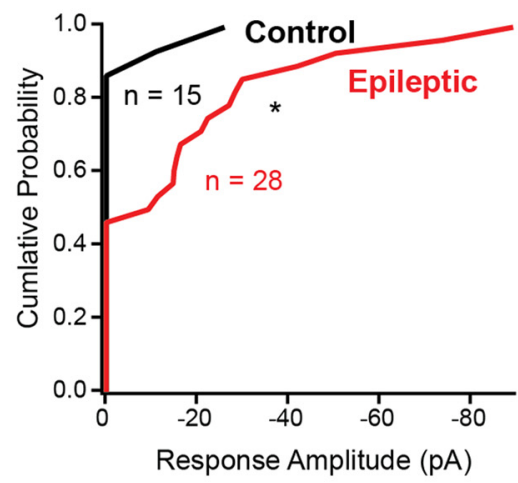

$\mathbf{F}$

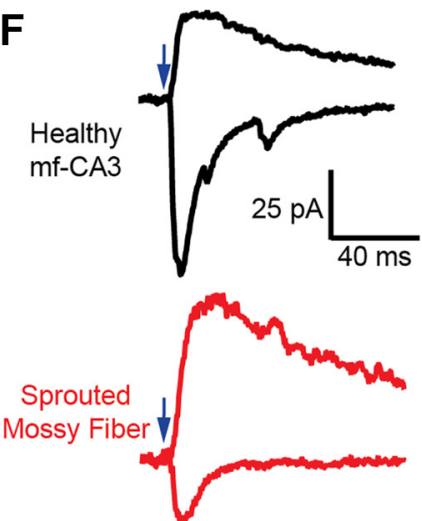

Scaled

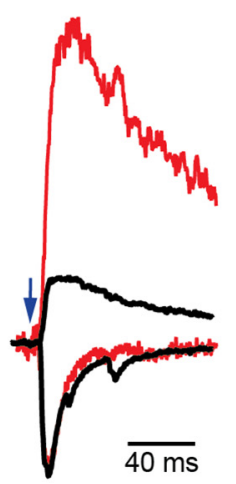

Figure 3. Sprouted mossy fibers from adult-born granule cells make monosynaptic excitatory connections with granule cells in pilocarpine-treated mice. $\boldsymbol{A}$, Experimental design for the recording of sprouted mossy fiber responses from adult-born granule cells. DcxCre::ChR2 mice received TAM to label granule cells that were immature at the time of SE; 2 months later, recordings were made from unlabeled granule cells. Timeline depicts the 2 week birth-dating window (orange) for labeled granule cells relative to TAM, SE, and electrophysiologic analysis. $\boldsymbol{B}$, Representative whole-cell voltage-clamp traces from ChR2-negative dentate granule cells in adult-labeled control (top) and epileptic (bottom) mice during optogenetic stimulation (1 ms, blue arrow) of labeled adult-born cells. Optogenetically evoked EPSCS (oEPSCs) were rarely observed in healthy control animals ( $n=2$ of 15 cells). C, Cumulative probability plot for functional sprouted mossy fiber innervation by adult-born neurons, demonstrating infrequent responses in control cells ( $n=2$ of 15 cells), but higher likelihood of responses in animals that had SE ( $n=15$ of 28 cells; $p=0.02$, Fisher's exact test). $D$, Sprouted mossy fibers from cells born shortly before SE formed functional monosynaptic excitatory connections with other granule cells. Monosynaptic currents were isolated in the presence of NBQX $(10 \mu \mathrm{m})$ to block polysynaptic activity, while holding the target cell at $+40 \mathrm{mV}$ to unblock NMDARs. Monosynaptic responses were observed in $n=5$ of 15 cells from epileptic mice, and in 0 of 15 cells from control mice. $E$, Sprouted mossy fiber currents were strongly inhibited by DCG-IV, similar to optogenetically evoked currents in healthy DcxCre::ChR2 mice in CA3 (percentage block by DCG-IV: control mossy fiber-CA3: $n=8$ cells; sprouted mossy fiber, $n=5$ cells; $t_{(8.00)}=0.31, p=0.76$, unpaired $t$ test). $\boldsymbol{F}$, Representative EPSCs from healthy CA3 (black traces) and sprouted mossy fiber synapses (red traces) at holding potentials of -70 and $+40 \mathrm{mV}$. Overlaid, peak-scaled traces (right) show relative increased NMDAR activation at sprouted mossy fiber synapses (red trace) compared with that of healthy mossy fiber-CA3 (mf-CA3) synapses (black trace). Sprouted mossy fiber synapses had a significantly decreased AMPA/NMDA ratio compared with healthy mossy fiber synapses (AMPA/NMDA ratio: healthy mossy fiber-CA3, $2.87 \pm 0.43, n=6 ;$ sprouted mossy fiber, $1.05 \pm 0.20, n=7 ; t_{(7.17)}=$ $3.84, p=0.006$, unpaired $t$ test;). ${ }^{*} p<0.05$.

between these possibilities, granule cells were routinely filled with Alexa Fluor 568 dye during recording, fixed, and imaged. In all cells imaged, all dendrites projected into the molecular layer, with no branches detected in the hilus $(0 \%, n=15)$, unequivocally demonstrating that these de novo monosynaptic EPSCs arose from retrogradely sprouted mossy fibers forming synapses onto granule cell apical dendrites.

Functional properties of the sprouted mossy fiber synapse Understanding the functional properties of sprouted mossy fiber synapses is critical to determining their contribution to hyperexcitable circuit formation in epilepsy. Although sprouted mossy fiber boutons are smaller than their counterparts in CA3 (Fig. 2), they are still much larger than typical CNS synapses and thus might be expected to retain many of the properties of healthy mossy fiber synapses in CA3. For example, mossy fiber synapses in CA3 have a low complement of postsynaptic NMDARs (Weisskopf and Nicoll, 1995). Surprisingly, however, sprouted mossy fiber responses had substantially greater complement of NMDARs than mossy fiber-CA3 synapses in age-matched healthy animals (Fig. $3 F$ ). The finding that these new synapses contain many NMDARs is consistent with the well characterized increase in hippocampal hyperexcitability due to NMDAR activation in epileptic tissue (Sutula et al., 1996; Lynch et al., 2000).

One of the most striking functional characteristics of mossy fiber-CA3 synapses is a profound frequency-dependent presynaptic facilitation of glutamate release (Salin et al., 1996). This phenomenon occurs with increased mossy fiber firing frequency, and therefore, if sprouted mossy fibers possessed a similar form of short-term plasticity, they could strongly contribute to recurrent excitatory network activation. Surprisingly, however, sprouted mossy fiber synapses did not exhibit frequency-dependent facilitation during higher-frequency $(1 \mathrm{~Hz})$ stimulation, but instead displayed frequency-dependent synaptic depression (Fig. 4A,B).

This frequency-dependent synaptic depression could be due to altered release probability $\left(P_{\mathrm{r}}\right)$ at the sprouted mossy fiber synapse. 
Consistent with this possibility, sprouted mossy fiber synapses had a decreased paired-pulse ratio compared with mossy fiber-CA3 connections (Fig. $4 C, D$ ), suggesting an increased initial $P_{\mathrm{r}}$, in stark contrast with the well characterized low $P_{\mathrm{r}}$ of mossy fiber-CA3 synapses (Bischofberger et al., 2006). Together, these data indicate that sprouted mossy fiber synapses have distinctly different release properties from healthy mossy fiber-CA3 synapses.

\section{Sprouted mossy fibers from mature} cells form functional monosynaptic connections with granule cells

Despite postnatal neurogenesis in the dentate gyrus, most granule cells are born neonatally (Kuhn et al., 1996). Studies examining whether these mature cells contributed to mossy fiber sprouting have yielded conflicting results (Kron et al., 2010; Althaus et al., 2016), raising the question of whether this population of cells contributes to recurrent excitatory circuit formation. Thus, we sought to determine whether cells born during neonatal development contributed to functional mossy fiber sprouting.

To identify sprouted mossy fiber boutons from neonatally born granule cells, we labeled these cells by administering TAM to DcxCre::tdT mice at P6, so the labeled cells would be fully mature at the onset of SE (P60). TAM injections at P6 labeled on average $346,200 \pm 70,300$ granule cells $/ \mathrm{mm}^{3}$ ( $n=4$ mice; Fig. $1 C$ ), comparatively greater than the labeling in adult mice $(19,600 \pm 3400$ granule cells/ $\mathrm{mm}^{3}, n=4$ mice; Fig. 1D), consistent with the known age-related decline in neurogenesis (Kuhn et al., 1996). First, we stained tissue from DcxCre::tdT mice with anti-ZnT3 antibodies 2 months after pilocarpine-induced SE, to assess whether any of the neonatally born cells contributed to mossy fiber sprouting. As shown in Figure $5 A$, we found a substantial number of $t \mathrm{dT}+/ \mathrm{ZnT} 3+$ sprouted mossy fiber boutons in the IML, indicating that neonatally born granule cells contributed to mossy fiber sprouting.

In whole-cell voltage-clamp recordings from unlabeled granule cells in slices from neonatally labeled DcxCre::ChR2 mice, 77\% of dentate granule cells had optogenetically evoked AMPARmediated EPSCs (average EPSC, cells with response: $-81.6 \pm$ $13.3 \mathrm{pA}, n=14$ of 18 cells; Fig. $5 B-D$ ). In the presence of NBQX to block polysynaptic activity, we again confirmed that sprouted mossy fiber EPSCs arose from monosynaptic granule cell-granule cell synapses (Fig. 5E,F). These EPSCs were blocked by DCG-IV (Fig. $5 B, E$ ), and no hilar basal dendrites were observed in granule cells filled with Alexa Fluor 568 dye ( $n=0$ of 14 cells), together confirming that the optogenetically evoked EPSCs derived from sprouted mossy fiber synapses. Sprouted mossy fiber synapses from these cells also had significantly increased NMDAR-mediated transmission (Fig. 5G), paired-pulse depres- sion (Fig. 5H), and frequency-dependent synaptic depression at $1 \mathrm{~Hz}$ (Fig. 5I) when compared with mossy fiber responses recorded in region CA3 from healthy (control) mouse slices. Together, our data definitively demonstrate that neonatally born granule cells sprout mossy fiber axons into the IML after seizures, and that these fibers form functional recurrent excitatory synapses.

\section{Adult-born sprouted mossy fibers have diminished ability to sustain recurrent excitation}

Sprouted mossy fiber synapses from both mature and adult-born granule cells shared many of the same functional properties, including similar AMPAR/NMDAR ratios (Mature, $1.38 \pm 0.35, n=7$ cells; Adult-born, $1.05 \pm 0.20, n=7$ cells; $t_{(9.56)}=0.80, p=0.44$, unpaired $t$ test), block by the Group II mGluR agonist DCG-IV (Fig. $6 A$ ), and paired-pulse depression (Fig. 6B). Notably, although both adult-born and neonatally born granule cells exhibited frequency-dependent depression of sprouted mossy fiber synaptic responses (Fig. 6C), this was much more pronounced at synapses formed by adult-born granule cells (Fig. 6D), despite similar presynaptic release probabilities (Fig. 6B) and EPSC kinet- 
A
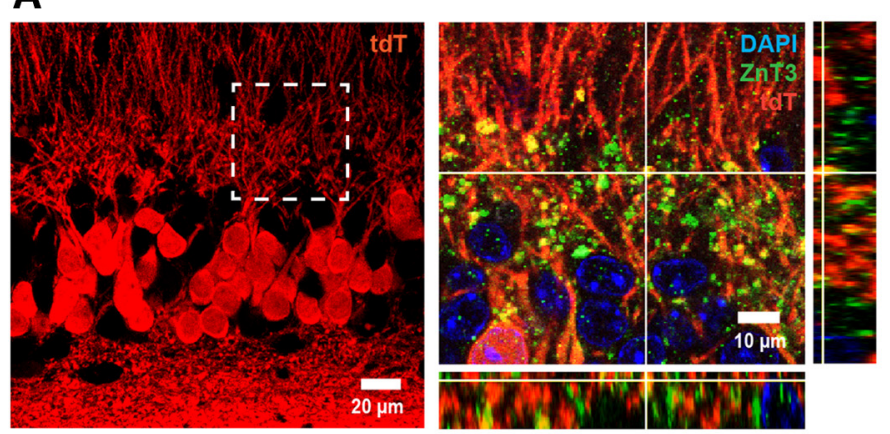

B

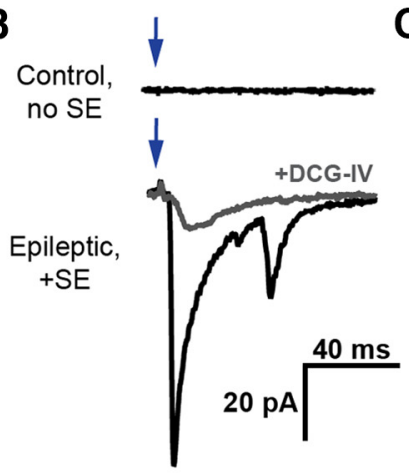

C

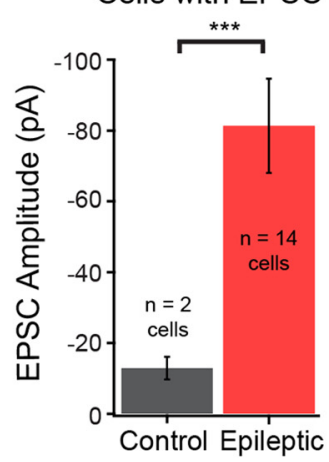

D

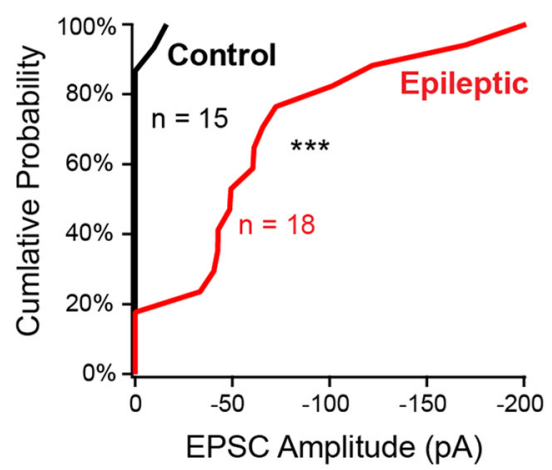

E

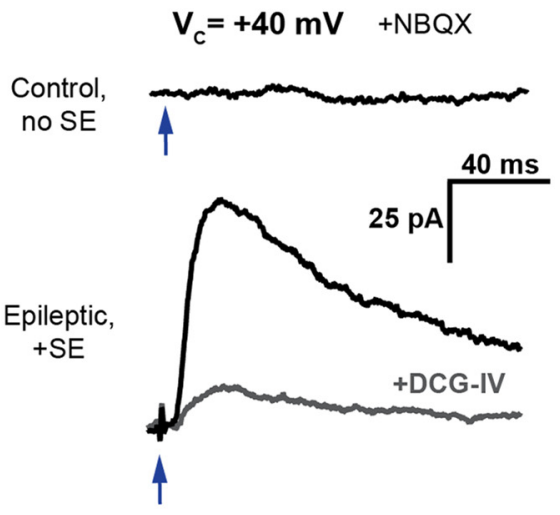

$\mathbf{F}$
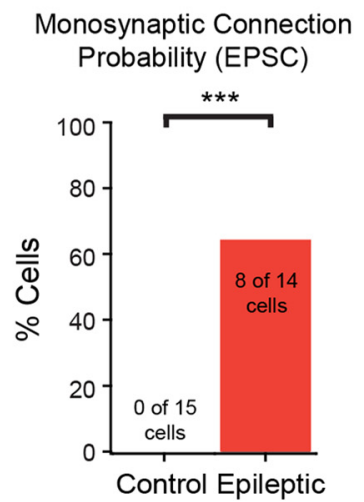

G

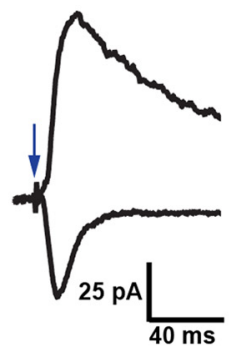

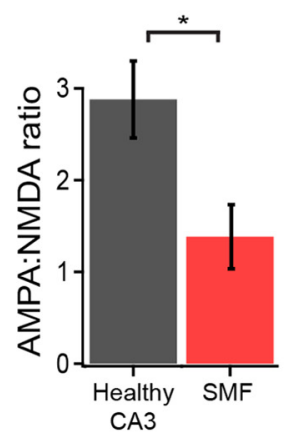

H
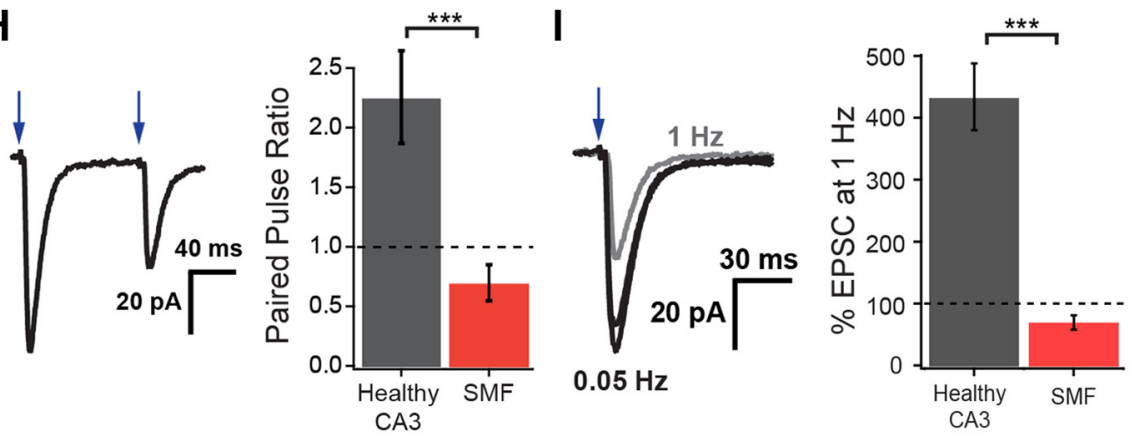

Figure 5. Neonatally born granule cells contribute to functional mossy fiber sprouting. $A$, Representative confocal images of tdT-labeled neonatally born granule cells (red) in $D c x(r e:: t d T$ animals given TAM at P6 demonstrate mossy fiber sprouting from these cells. Dashed box indicates corresponding locations from compressed stack image (left) represented in an orthogonal single-plane projection (right). Mossy fiber terminals are labeled with ZnT3 (green). Nuclei are labeled with DAPI (blue). B, Representative averaged evoked responses recorded from ChR2-negative granule cells in control (top) and epileptic (bottom) neonatally labeled DcxCre:: ChR2 animals during optogenetic stimulation of ChR2-expressing granule cells. Gray trace is the average evoked optogenetically evoked EPSC ( 0 EPSC) following wash-in of $1 \mu \mathrm{M}$ DCG-IV.C, In the subset of cells with an observable optogenetically evoked response, average oEPSC amplitude was substantially greater in recordings from epileptic mice (Control, $n=2$ cells; Epileptic, $n=14$ cells; $t_{(13.9)}=4.70, p=0.0003$, unpaired $t$ test). $\boldsymbol{D}$, Cumulative probability plot for the occurrence of oEPSCs in control (black) and epileptic (red) mice recorded while voltage clamping the recorded cell to $-70 \mathrm{mV}$. EPSCs from granule cells in epileptic mice were substantially larger and more frequent than those found in controls (response likelihood: Control, 2 of 15 cells with oEPSC; Epileptic, 14 of 18 cells with oEPSC, Fisher's exact test, $p=0.0004$ ). E, Monosynaptic sprouted granule cell-granule cell synapses were only observed in pilocarpine-treated mice (bottom trace), and not in controls (top trace). Monosynaptic NMDAR-mediated currents were recorded from cells voltage-clamped to $+40 \mathrm{mV}$, while blocking polysynaptic responses with NBQX $(10 \mu \mathrm{M})$. $\boldsymbol{F}$, Probability of monosynaptic granule cell-granule cell connections. Neither of the two control cells that had oEPSCs depicted in $\boldsymbol{C}$ had an NMDARmediated response in the presence of NBQX, suggesting that these responses were polysynaptic. Eight cells assayed at $+40 \mathrm{mV}$ in epileptic mice had a monosynaptic recurrent connection (Control: 0 of 15 cells; Epileptic: 8 of 14 cells; $p=0.0007$, Fisher's exact test). G, Representative EPSCs from sprouted mossy fiber synapses (left) at holding potentials of -70 and $+40 \mathrm{mV}$. Mean AMPAR/NMDAR ratios (right) demonstrate a significantly increased relative NMDAR-mediated contribution at sprouted mossy fiber synapses (AMPAR/NMDAR ratio: healthy mossy fiber-CA3, $n=$ 7; sprouted mossy fiber, $n=10 ; t_{(10.2)}=2.69, p=0.022$, unpaired $t$ test). $\boldsymbol{H}$, Paired-pulse depression at sprouted mossy fiber synapses from neonatally born granule cells (left). The mean paired-pulse ratio (right; $100 \mathrm{~ms}$ interval) was significantly less at sprouted mossy fiber synapses after SE when compared with mossy fiber-CA3 responses (EPSC /EPSC $_{1}$ : healthy mossy fiber-CA3, $n=6$; sprouted mossy fiber, $n=9 ; t_{(7.83)}=5.21, p=0.0009$, unpaired $t$ test). $I$, Example traces (left) of sprouted mossy fiber-granule cell synapses during $0.05 \mathrm{~Hz}$ (black traces) and $1 \mathrm{~Hz}$ stimulation (gray traces) of neonatally born granule cells from post-SE mice. Sprouted mossy fibers exhibit frequency-dependent depression whereas mossy fiber-CA3 connections exhibit frequency-dependent facilitation (right; control mossy fiber-CA3, $n=6$; sprouted mossy fiber, $n=8 ; t_{(5.29)}=6.75, p=0.0009$, unpaired $t$ test). All data presented as average \pm SEM. ${ }^{*} p<0.05$, ${ }^{* * *} p<0.001$.

ics (single exponential decay: Mature, $\tau=10.4 \pm 0.9 \mathrm{~ms}, n=8$ cells; Adult-born, $\tau=12.3 \pm 1.6 \mathrm{~ms}, n=7$ cells, $t_{(10.35)}=1.05, p=0.32$, unpaired $t$ test). The enhanced synaptic depression of adult-born cells occurred at the onset of higher-frequency stimulation (1
$\mathrm{Hz}$ ) and was sustained throughout the 50-pulse train (Fig. $6 D)$. Thus, recurrent excitatory synapses from adult-born granule cells were less able to sustain repetitive activation than their neonatally derived counterparts. 
A

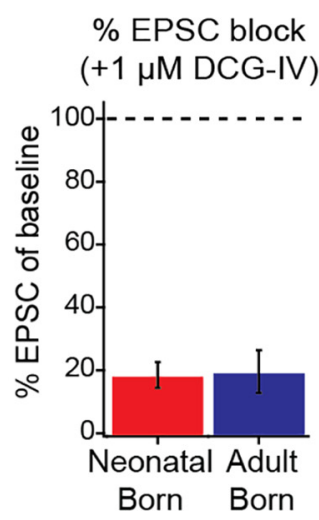

B

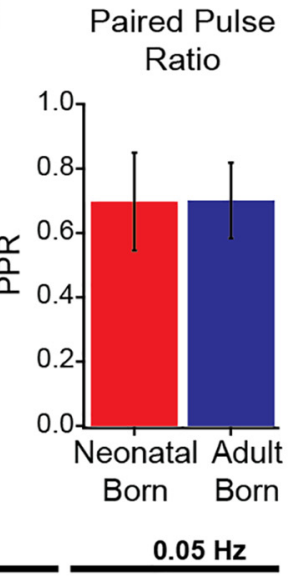

C

$$
\begin{gathered}
\text { Neonatally } \\
\text { Born }
\end{gathered}
$$
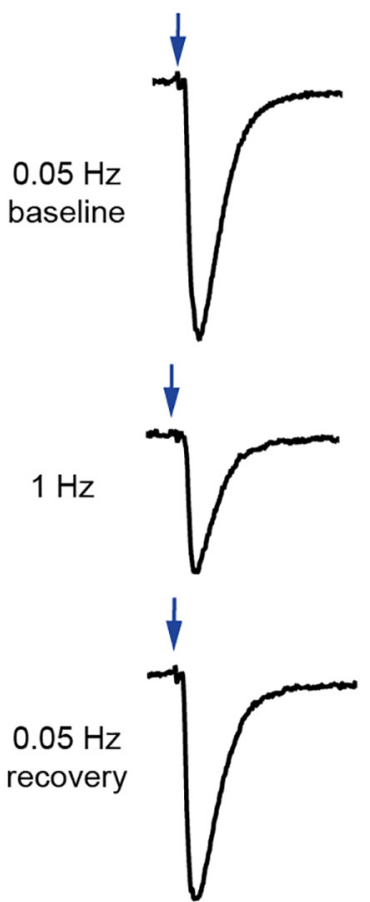

\section{Adult Born}
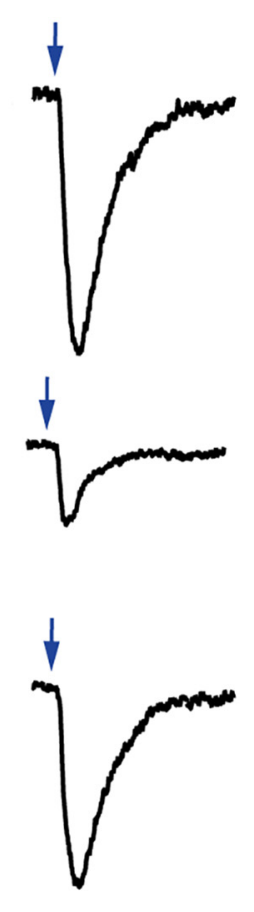

D

$0.05 \mathrm{~Hz}$

$1 \mathrm{~Hz}$
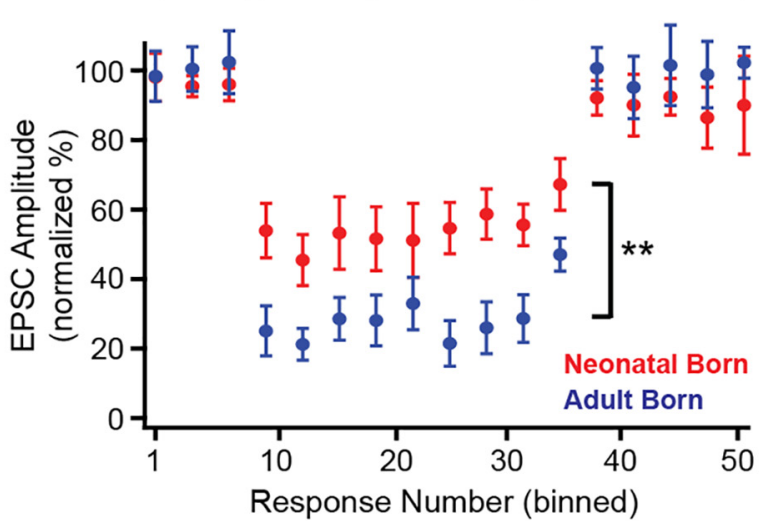
so

Figure 6. Sprouted mossy fiber synapses made by adult-born granule cells have enhanced short-term depression compared with those from neonatally born cells. $\boldsymbol{A}$, Sprouted mossy fiber synapses from neonatally born and adult-born granule cells have comparable block by $1 \mu \mathrm{m} \mathrm{DCG-IV} \mathrm{(percentage} \mathrm{EPSC:} \mathrm{Neonatal,} n=8 ;$ Adult-born, $n=5 ; t_{(10.58)}=0.92, p=0.39$, unpaired $t$ test). $\boldsymbol{B}$, Comparable paired-pulse depression in sprouted mossy fiber synapses from both neonatally born and adult-born granule cells (paired-pulse ratio: Neonatal, $n=9 ;$ Adult-born, $n=5 ; t_{(11.92)}=$ $0.02, p=0.983$, unpaired $t$ test). C, Example frequency-dependent depression of sprouted mossy fiber optogenetically evoked EPSCs (oEPSCs) from neonatally born (left) and adult-born (right) granule cells upon $1 \mathrm{~Hz}$ stimulation. Baseline stimulation was $0.05 \mathrm{~Hz}$. Vertical scale between cells are normalized to the amplitude of the first EPSC; all responses for each cell are on the same vertical scale. D, Sprouted synapses from adult-born granule cells displayed enhanced short-term depression compared with cells born neonatally. Average steady-state (last 10 traces) EPSC depression from baseline was significantly greater in synapses from adult-born granule cells (Neonatal: $n=8$; Adult-born: $n=10 ; t_{(7.89)}=4.20, p=0.003$, unpaired $t$ test). All data represented as average \pm SEM. ${ }^{* *} p<0.01$.

\section{No functional sprouted synapses from granule cells born after SE}

Hippocampal neurogenesis is increased by seizures, and granule cells born after SE contribute to mossy fiber sprouting, albeit with some delay (Kron et al., 2010; Althaus et al., 2016). We examined whether synapses from cells born after SE shared similar functional properties with other sprouted mossy fiber synapses. We pulse-labeled granule cells born after pilocarpine-induced SE in DcxCre mice, by administering TAM 2 weeks after SE. Despite the presence of tdT-labeled sprouted mossy fiber synapses from this cohort of cells in DcxCre::tdT mice (Fig. 7A), we were not able to optogenetically evoke any sprouted mossy fiber EPSCs when we examined acute slices from this same cell cohort in DcxCre::ChR2 mice (response frequency: post-SE, $0 \%, n=0$ of 18 cells; pre-SE, $54 \%, n=15$ of 28 cells; pre-SE vs post-SE $p<0.0001$, Fisher's exact test; Fig. $7 B, C)$.

Because the circuit impact of sprouted mossy fibers depends on when the respective granule cells from which they derived were born (Figs. 6, 7), we attempted to approximately determine the relative contribution of the different granule cell cohorts (neonatally born, adult-born before SE, adult-born after SE) to mossy fiber sprouting. Using confocal microscopy to examine thin optical sections $(0.38 \mu \mathrm{m})$ of tissue from DcxCre::tdT mice, we found comparable densities of $\mathrm{tdT}+$ sprouted mossy fiber boutons in slices labeled at the corresponding time points for each cohort of granule cells (Fig. $8 A-D$ ) despite marked differences in the number of labeled cells across cohorts (Fig. 1C,D). We calculated a "sprouting ratio" for each animal, defined as the ratio of $\mathrm{tdT}+/ \mathrm{ZnT} 3+$ mossy fiber bouton density in the IML to the density of tdT +-labeled granule cells in the granule cell layer, to represent the relative likelihood that a cell from a given cohort formed sprouted boutons. The sprouting ratio of either cohort of adult-born granule cells was significantly higher than that of neonatally born granule cells (Fig. $8 E$ ), suggesting these cells may be the most likely to sprout.

\section{Discussion}

Here, we demonstrate that both neonatally born and adult-born granule cells generate sprouted mossy fibers and form functional monosynaptic excitatory granule cell-granule cell connections. Sprouted synapses had strikingly different functional properties than mossy fiber-CA3 synapses in healthy brains, despite retaining similar morphological characteristics. Adult-born granule cells generated just before SE were most susceptible to developing sprouted fibers, and had more pronounced functional changes than sprouted synapses formed by granule cells generated neonatally. 
A
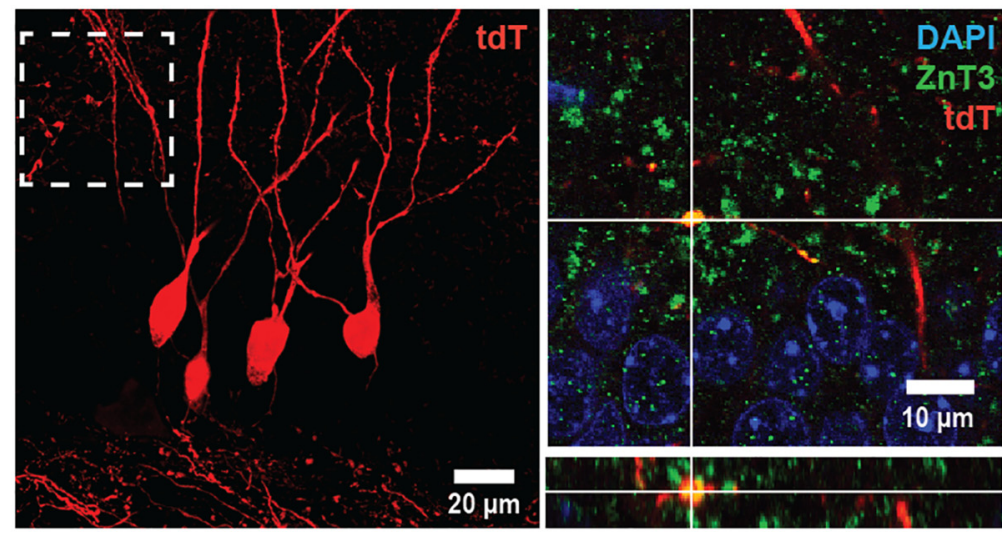

B
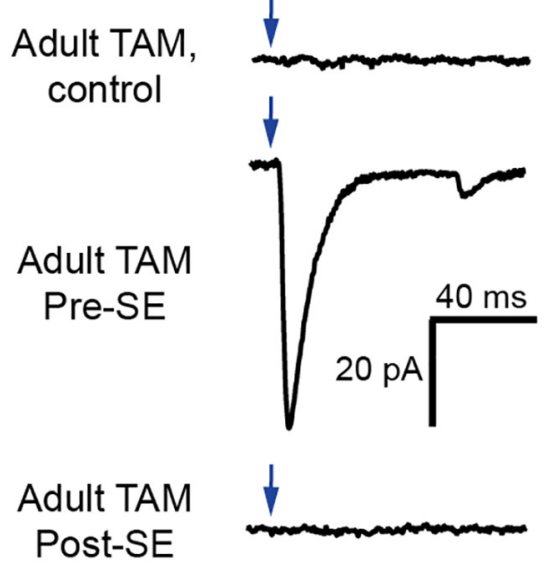

C

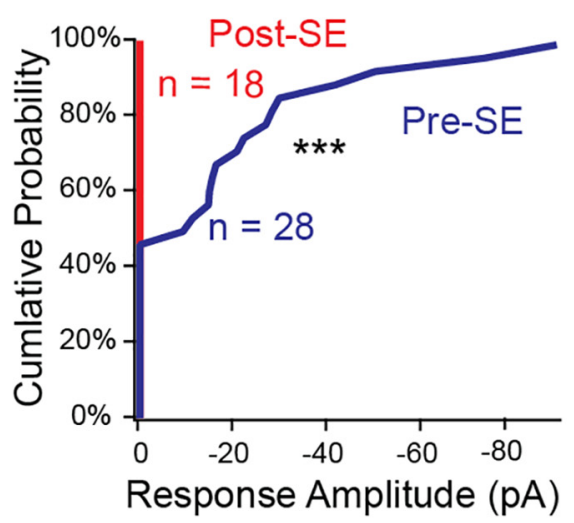

Figure 7. Sprouted mossy fiber synapses from granule cells born after seizures do not form functional excitatory synapses by 2 months after SE. A, Representative confocal images from tdT-labeled adult-born granule cells (red) in animals given TAM after SE demonstrate robust mossy fiber sprouting from cells born after $S E$. Dashed box indicates corresponding location from compressed stack image (left) represented in orthogonal single-plane projection (right). Mossy fiber terminals are labeled with ZnT3 (green) and nuclei with DAPI (blue). $\boldsymbol{B}$, Representative whole-cell voltage-clamp traces from unlabeled dentate granule cells during stimulation of ChR2-expressing granule cells in adult-labeled healthy control mice (top), from adult-born cells generated before SE (mice given TAM pre-SE; middle), and granule cells born after SE (mice given TAM 2 weeks post-SE; bottom). Optogenetically evoked EPSCS (oEPSCS) were not observed during stimulation of granule cells born after SE. Scale is identical for all traces. C, Cumulative probability plot for functional sprouted mossy fiber innervation by adult-born neurons, demonstrating no responses from ChR2-positive granule cells born post-SE ( $n=0$ of 18 cells), with frequent sprouted mossy fiber-mediated responses from ChR2-positive adult-born cells born pre-SE ( $n=15$ of 28 cells; $p<0.0001$, Fisher's exact test). ${ }^{* * *} p<0.001$.

\section{Divergence of function in sprouted mossy fiber boutons}

Mossy fiber-CA3 synapses in healthy tissue form potent synapses onto proximal CA3 dendrites, and tend to dramatically facilitate in response to repetitive stimulation (Salin et al., 1996), leading to their designation as "detonator" synapses that can drive CA3 cell spiking in response to activity at a single synapse (Henze et al., 2002; Sachidhanandam et al., 2009; Vyleta et al., 2016). Thus, recurrent mossy fiber synapses with these properties could easily drive synchronized granule cell discharges through recurrent circuits and, upon repetitive activation, lead to ever-increasing positive feedback. Our data, however, suggest that sprouted mossy fiber synapses rapidly fatigue during repetitive activation, as evidenced by their paired-pulse depression and $1 \mathrm{~Hz}$ frequency-dependent depression, which would be expected to dampen the ability of these synapses to drive multiple rounds of recurrent excitation. However, sprouted mossy fiber synapses might still be able to potently drive granule cell spiking due to the epilepsy-induced increase in postsynaptic kainate receptor expression in granule cells (Epsztein et al., 2005; Artinian et al., 2011). Slower kinetics of kainate receptor-mediated EPSPs could enhance temporal summation
. mechanisms underlying altered $P_{\mathrm{r}}$ likely involve complex interactions between expression and phosphorylation of presynaptic proteins, neuromodulatory factors, and the potentiation state of synapses, all of which could broadly alter synaptic function in the epileptic brain.

\section{Consequences of sprouted mossy fiber activity on hippocampal hyperexcitability}

The intermingling of sprouted mossy fibers with other granule cell inputs has impeded our understanding of their impact on neural network dynamics in epileptic brains, and functional evidence that sprouted mossy fibers form recurrent excitatory synapses has long relied upon indirect, albeit elegantly designed, experiments. The presence/absence of mossy fiber sprouting has been correlated with abnormal responses of granule cells to antidromic hilar/CA3 stimulation (Tauck and Nadler, 1985; Wuarin and Dudek, 1996; Okazaki et al., 1999), suprathreshold perforant pulse stimulation (Cronin et al., 1992; Golarai and Sutula, 1996; Masukawa et al., 1996; Patrylo et al., 1999), focal glutamate application (Wuarin and Dudek, 1996; Lynch et al., 2000), or glutamate uncaging in the granule cell layer (Molnár and Nadler, 


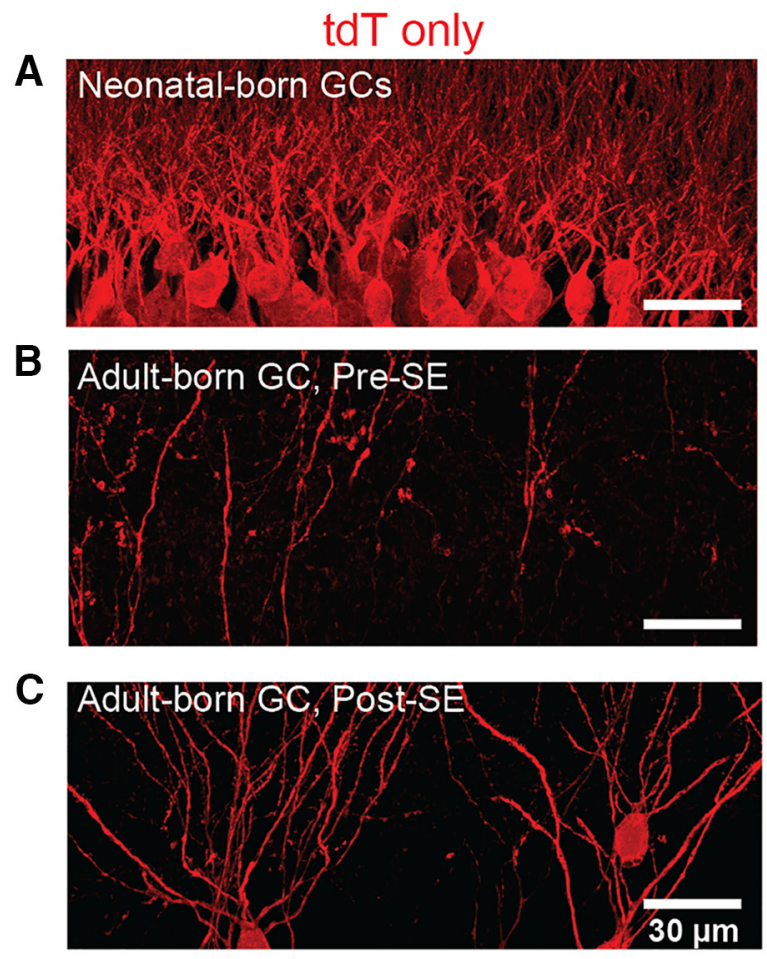

\section{Sprouted Boutons (ZnT3+)}
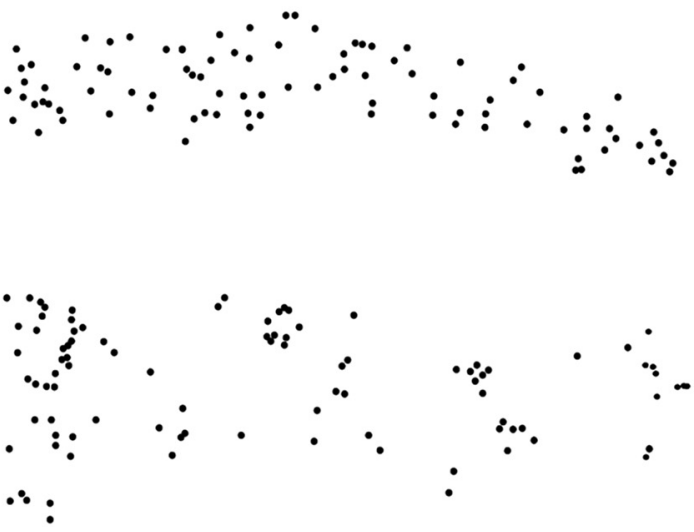

D

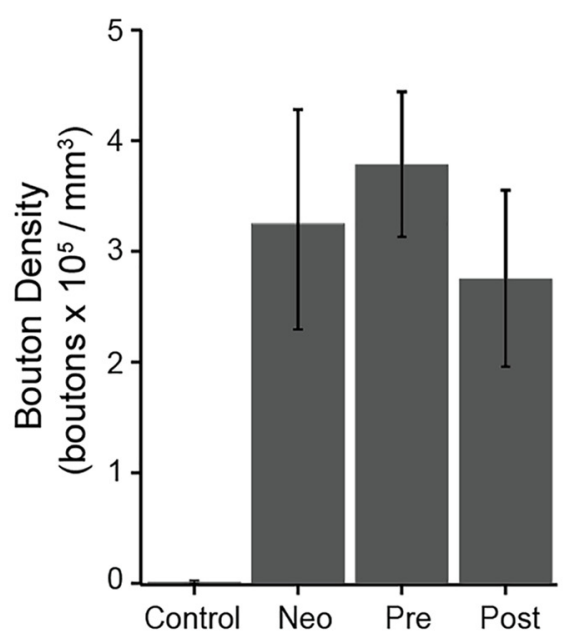

E

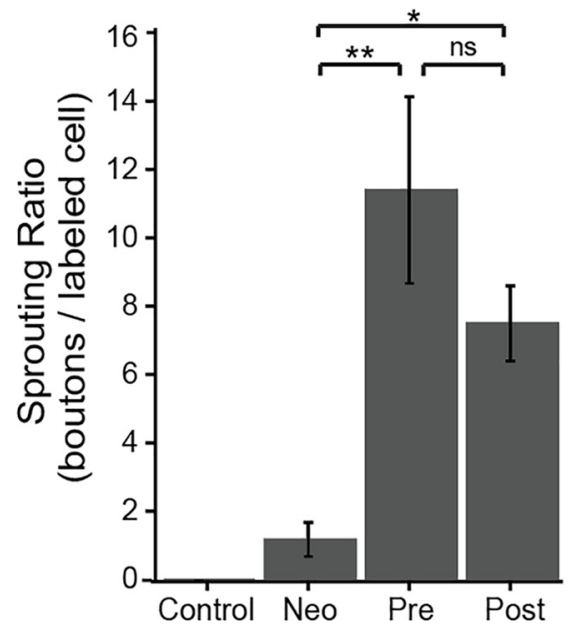

Figure 8. Adult-born granule cells are more likely to form sprouted mossy fiber boutons than neonatally born granule cells. $\boldsymbol{A}$, Example compressed $20 \mu \mathrm{m}$ confocal stack of tdT-labeled, neonatally born granule cells (red) from pilocarpine-treated $D c x$ Cre::tdT mice (left). Sprouted tdT + boutons were identified using thin confocal sections and colabeling with ZnT3 (as in Fig. $5 A$ ) and the localization of sprouted mossy fiber boutons (tdT $+/ Z n T 3+$ ) in this stack is represented by black dots (shown on right). ZnT3 staining omitted for clarity. $B$, Example compressed confocal stack of tdT-labeled, adult-born granule cells born pre-SE (red) from pilocarpine-treated DcxCre::tdT mice (left) and corresponding localization of sprouted (tdT $+Z n T 3+$ ) mossy fiber boutons (black dots, right). C, Example compressed confocal stack of tdT-labeled, adult-born granule cells born post-SE (red) from pilocarpine-treated DexCre::tdT mice (left) and corresponding localization of sprouted $(\mathrm{tdT}+\mathrm{ZnT} 3+)$ mossy fiber boutons (black dots, right). D, Sprouted tdT + bouton density in the IML after SE is similar across all labeling cohorts despite dramatic differences in the density of labeled neurons (bouton density: Neonatal, $n=6$; Pre-SE, $n=4 ;$ Post-SE, $n=4 ; F_{(2,11)}=0.27, p=0.77$, ANOVA). Controls did not have any sprouting (Control, $n=5$ mice). $\boldsymbol{E}$, Granule cells from adult-born cells had significantly more sprouted boutons per labeled neuron, represented as an increase in their sprouting ratio (sprouted bouton density/labeled cell density; Neonatal, $n=6$; Pre-SE, $n=4 ;$ Post-SE, $n=4 ; F_{(2,11)}=4.82, p=0.03$, ANOVA; Neonatal vs Pre-SE, $p=0.001$; Neonatal vs Post-SE, $p=0.04$, Tukey's post hoc test; $n$ no difference between Pre-SE and Post-SE, $p=$ 0.29). Controls did not have any sprouting (Control, $n=5$ mice).

1999; Wuarin and Dudek, 2001). Using paired recordings of granule cells, Scharfman et al. (2003) observed putative monosynaptic granule cell-granule cell connectivity in epileptic rats with seizure-induced mossy fiber sprouting. However, disynaptic pathways remained intact, and although response latencies were appropriately short $(4 \mathrm{~ms})$, there remained the possibility that some evoked EPSPs were polysynaptic. Regardless, the low connection probability between any two granule cells (six connected in 902 pairs) and inability to perform voltage-clamp recordings in these experiments precluded functional characterization of these synapses.

By pulse labeling and optogenetically stimulating granule cell cohorts, we bulk-activated sprouted synapses, dramatically improving our ability to directly study the connections formed by these fibers. This selective stimulation of sprouted mossy fiber synapses eliminates the need to use paired recordings to selec- 
tively stimulate presynaptic granule cells, and as such, allowed us to characterize sprouted mossy fiber function in a direct manner to more precisely determine its effects on the hippocampal circuit.

Despite the potential for recurrent mossy fiber synapses to drive seizure activity, questions have been raised regarding the involvement of sprouted mossy fibers in the occurrence of spontaneous seizures in epilepsy (Buckmaster, 2014). In some studies, suppression of mossy fiber sprouting with rapamycin reduced seizure frequency (Zeng et al., 2009; Huang et al., 2010). However, rapamycin has multiple other effects (Wong, 2013) and does not reduce seizure frequency when sprouting is diminished but remains present at a lower level (Buckmaster and Lew, 2011; Heng et al., 2013). Additionally, both the nature of the synaptic connection (excitatory vs inhibitory; Gutiérrez, 2000), as well as the targets of the sprouted mossy fibers (Sloviter et al., 2006) have been questioned. Although our results demonstrate that mossy fibers form recurrent excitatory connections with other granule cells, the propagation of this activity out of the dentate gyrus might only occur in association with additional pathology, such as the loss of various interneuron populations (Sloviter, 1987; Doherty and Dingledine, 2001) and sprouting into CA2 (Althaus et al., 2016; Häussler et al., 2016), any of which could be critical for the occurrence of spontaneous generalized seizures.

\section{Significance of adult-born granule cells in the epileptic hippocampus}

Consistent with prior work (Jessberger et al., 2007; Kron et al., 2010; Althaus et al., 2016), our results demonstrate that adultborn granule cells robustly contribute to mossy fiber sprouting, and form functional recurrent synapses (Figs. 2, 8). However, neonatally born neurons also contributed substantially to sprouting, consistent with some reports (Parent et al., 1999; Althaus et al., 2016), but not others (Kron et al., 2010). These discrepancies could have resulted from the possibility that only a small proportion of neonatally born cells sprout, or from differences in the detection of sprouted mossy fibers between various labeling techniques (Althaus et al., 2016). The ability of all cohorts of granule cells to form sprouted mossy fibers may explain why potent suppression of neurogenesis (Parent et al., 1999; Cho et al., 2015; Hosford et al., 2016) failed to block mossy fiber sprouting, and why inhibition of neurogenesis at earlier time points was only partially successful (Kron et al., 2010).

Considering the increase in neurogenesis after seizures (Parent et al., 1997, 2006; Jessberger et al., 2005, 2007), it seems likely that ongoing generation of adult-born granule cells leads to a continual accumulation of sprouted mossy fibers, which is further worsened by the recurrence of seizures in epileptic animals. However, although adult neurogenesis may continue to drive the accumulation of sprouted mossy fiber synapses over time, the enhanced frequency-dependent depression of these adult-born synapses may mitigate their contribution to hyperexcitability. Interestingly, disruption of adult neurogenesis reduced seizure frequency while simultaneously increasing seizure duration (Hosford et al., 2016), further indicating that the role of adultborn granule cells in epileptogenesis is likely dualistic. A surprising result was our inability to observe functional sprouted mossy fiber responses from granule cells born after SE (Fig. 7), despite the presence of robust morphologic mossy fiber sprouting by these cells. This observation could be related to the previously described delay in the formation of anatomically detectable sprouted mossy fiber synapses by this population of cells (Kron et al., 2010), which could then lead to a delay in their functional activation. Although adult-born cells form functional output synapses as early as 2 weeks postmitosis in healthy brains ( $\mathrm{Gu}$ et al., 2012), fibers from cells born after SE likely arrive in the IML later than those from previously existing granule cells, further delaying their maturation. However, if these synapses remain unable to drive recurrent excitation, and sprouted boutons from adult-born neurons continue to accumulate over time, most recurrent synapses in the IML would be incapable of sustaining repeated activation or could even remain functionally silent.

\section{References}

Acsády L, Kamondi A, Sík A, Freund T, Buzsáki G (1998) GABAergic cells are the major postsynaptic targets of mossy fibers in the rat hippocampus. J Neurosci 18:3386-3403. Medline

Althaus AL, Zhang H, Parent JM (2016) Axonal plasticity of age-defined dentate granule cells in a rat model of mesial temporal lobe epilepsy. Neurobiol Dis 86:187-196. CrossRef Medline

Artinian J, Peret A, Marti G, Epsztein J, Crépel V (2011) Synaptic kainate receptors in interplay with $\mathrm{INaP}$ shift the sparse firing of dentate granule cells to a sustained rhythmic mode in temporal lobe epilepsy. J Neurosci 31:10811-10818. CrossRef Medline

Babb TL, Lieb JP, Brown WJ, Pretorius J, Crandall PH (1984) Distribution of pyramidal cell density and hyperexcitability in the epileptic human hippocampal formation. Epilepsia 25:721-728. CrossRef Medline

Bengzon J, Kokaia Z, Elmér E, Nanobashvili A, Kokaia M, Lindvall O (1997) Apoptosis and proliferation of dentate gyrus neurons after single and intermittent limbic seizures. Proc Natl Acad Sci U S A 94:10432-10437. CrossRef Medline

Bischofberger J, Engel D, Frotscher M, Jonas P (2006) Timing and efficacy of transmitter release at mossy fiber synapses in the hippocampal network. Pflugers Arch 453:361-372. CrossRef Medline

Brown JP, Couillard-Després S, Cooper-Kuhn CM, Winkler J, Aigner L, Kuhn HG (2003) Transient expression of doublecortin during adult neurogenesis. J Comp Neurol 467:1-10. CrossRef Medline

Buckmaster PS (2014) Does mossy fiber sprouting give rise to the epileptic state? Adv Exp Med Biol 813:161-168. CrossRef Medline

Buckmaster PS, Lew FH (2011) Rapamycin suppresses mossy fiber sprouting but not seizure frequency in a mouse model of temporal lobe epilepsy. J Neurosci 31:2337-2347. CrossRef Medline

Buckmaster PS, Zhang GF, Yamawaki R (2002) Axon sprouting in a model of temporal lobe epilepsy creates a predominantly excitatory feedback circuit. J Neurosci 22:6650-6658. Medline

Cavalheiro EA, Santos NF, Priel MR (1996) The pilocarpine model of epilepsy in mice. Epilepsia 37:1015-1019. CrossRef Medline

Chang BS, Lowenstein DH (2003) Epilepsy. N Engl J Med 349:1257-1266. CrossRef Medline

Cheng X, Li Y, Huang Y, Feng X, Feng G, Xiong ZQ (2011) Pulse labeling and long-term tracing of newborn neurons in the adult subgranular zone. Cell Res 21:338-349. CrossRef Medline

Cho KO, Lybrand ZR, Ito N, Brulet R, Tafacory F, Zhang L, Good L, Ure K, Kernie SG, Birnbaum SG, Scharfman HE, Eisch AJ, Hsieh J (2015) Aberrant hippocampal neurogenesis contributes to epilepsy and associated cognitive decline. Nat Commun 6:6606. CrossRef Medline

Cronin J, Obenaus A, Houser CR, Dudek FE (1992) Electrophysiology of dentate granule cells after kainate-induced synaptic reorganization of the mossy fibers. Brain Res 573:305-310. CrossRef Medline

Danzer SC, He X, Loepke AW, McNamara JO (2010) Structural plasticity of dentate granule cell mossy fibers during the development of limbic epilepsy. Hippocampus 20:113-124. CrossRef Medline

DeGiorgio CM, Tomiyasu U, Gott PS, Treiman DM (1992) Hippocampal pyramidal cell loss in human status epilepticus. Epilepsia 33:23-27. CrossRef Medline

Doherty J, Dingledine R (2001) Reduced excitatory drive onto interneurons in the dentate gyrus after status epilepticus. J Neurosci 21:2048-2057. Medline

Epsztein J, Represa A, Jorquera I, Ben-Ari Y, Crépel V (2005) Recurrent mossy fibers establish aberrant kainate receptor-operated synapses on granule cells from epileptic rats. J Neurosci 25:8229-8239. CrossRef Medline

Frotscher M, Zimmer J (1983) Lesion-induced mossy fibers to the molecular layer of the rat fascia dentata: identification of postsynaptic granule 
cells by the Golgi-EM technique. J Comp Neurol 215:299-311. CrossRef Medline

Golarai G, Sutula TP (1996) Functional alterations in the dentate gyrus after induction of long-term potentiation, kindling, and mossy fiber sprouting. J Neurophysiol 75:343-353. Medline

Goussakov IV, Fink K, Elger CE, Beck H (2000) Metaplasticity of mossy fiber synaptic transmission involves altered release probability. J Neurosci 20:3434-3441. Medline

Gu Y, Arruda-Carvalho M, Wang J, Janoschka SR, Josselyn SA, Frankland PW, Ge S (2012) Optical controlling reveals time-dependent roles for adult-born dentate granule cells. Nat Neurosci 15:1700-1706. CrossRef Medline

Gutiérrez R (2000) Seizures induce simultaneous GABAergic and glutamatergic transmission in the dentate gyrus-CA3 system. J Neurophysiol 84: 3088-3090. Medline

Häussler U, Rinas K, Kilias A, Egert U, Haas CA (2016) Mossy fiber sprouting and pyramidal cell dispersion in the hippocampal CA2 region in a mouse model of temporal lobe epilepsy. Hippocampus 26:577-588. CrossRef Medline

Heng K, Haney MM, Buckmaster PS (2013) High-dose rapamycin blocks mossy fiber sprouting but not seizures in a mouse model of temporal lobe epilepsy. Epilepsia 54:1535-1541. CrossRef Medline

Henze DA, Wittner L, Buzsáki G (2002) Single granule cells reliably discharge targets in the hippocampal CA3 network in vivo. Nat Neurosci 5:790-795. Medline

Hosford BE, Liska JP, Danzer SC (2016) Ablation of newly generated hippocampal granule cells has disease-modifying effects in epilepsy. J Neurosci 36:11013-11023. CrossRef Medline

Huang X, Zhang H, Yang J, Wu J, McMahon J, Lin Y, Cao Z, Gruenthal M, Huang Y (2010) Pharmacological inhibition of the mammalian target of rapamycin pathway suppresses acquired epilepsy. Neurobiol Dis 40: 193-199. CrossRef Medline

Jessberger S, Römer B, Babu H, Kempermann G (2005) Seizures induce proliferation and dispersion of doublecortin-positive hippocampal progenitor cells. Exp Neurol 196:342-351. CrossRef Medline

Jessberger S, Zhao C, Toni N, Clemenson GD Jr, Li Y, Gage FH (2007) Seizure-associated, aberrant neurogenesis in adult rats characterized with retrovirus-mediated cell labeling. J Neurosci 27:9400-9407. CrossRef Medline

Kourdougli N, Pellegrino C, Renko JM, Khirug S, Chazal G, Kukko-Lukjanov TK, Lauri SE, Gaiarsa JL, Zhou L, Peret A, Castrén E, Tuominen RK, Crépel V, Rivera C (2017) Depolarizing GABA contributes to glutamatergic network rewiring in epilepsy. Ann Neurol 81:251-265. CrossRef Medline

Kron MM, Zhang H, Parent JM (2010) The developmental stage of dentate granule cells dictates their contribution to seizure-induced plasticity. J Neurosci 30:2051-2059. CrossRef Medline

Kuhn HG, Dickinson-Anson H, Gage FH (1996) Neurogenesis in the dentate gyrus of the adult rat: age-related decrease of neuronal progenitor proliferation. J Neurosci 16:2027-2033. Medline

Lynch M, Sayin U, Golarai G, Sutula T (2000) NMDA receptor-dependent plasticity of granule cell spiking in the dentate gyrus of normal and epileptic rats. J Neurophysiol 84:2868-2879. Medline

Masukawa LM, Wang H, O'Connor MJ, Uruno K (1996) Prolonged field potentials evoked by $1 \mathrm{~Hz}$ stimulation in the dentate gyrus of temporal lobe epileptic human brain slices. Brain Res 721:132-139. CrossRef Medline

Mello LE, Cavalheiro EA, Tan AM, Kupfer WR, Pretorius JK, Babb TL, Finch DM (1993) Circuit mechanisms of seizures in the pilocarpine model of chronic epilepsy: cell loss and mossy fiber sprouting. Epilepsia 34:985995. CrossRef Medline

Molnár P, Nadler JV (1999) Mossy fiber-granule cell synapses in the normal and epileptic rat dentate gyrus studied with minimal laser photostimulation. J Neurophysiol 82:1883-1894. Medline

Nadler JV, Perry BW, Cotman CW (1980) Selective reinnervation of hippocampal area CA1 and the fascia dentata after destruction of CA3-CA4 afferents with kainic acid. Brain Res 182:1-9. CrossRef Medline

Okazaki MM, Evenson DA, Nadler JV (1995) Hippocampal mossy fiber sprouting and synapse formation after status epilepticus in rats: visualization after retrograde transport of biocytin. J Comp Neurol 352:515-534. CrossRef Medline

Okazaki MM, Molnar P, Nadler JV (1999) Recurrent mossy fiber pathway in rat dentate gyrus: synaptic currents evoked in presence and absence of seizure-induced growth. J Neurophysiol 81:1645-1660. Medline

Overstreet-Wadiche LS, Bromberg DA, Bensen AL, Westbrook GL (2006) Seizures accelerate functional integration of adult-generated granule cells. J Neurosci 26:4095-4103. CrossRef Medline

Parent JM, Yu TW, Leibowitz RT, Geschwind DH, Sloviter RS, Lowenstein DH (1997) Dentate granule cell neurogenesis is increased by seizures and contributes to aberrant network reorganization in the adult rat hippocampus. J Neurosci 17:3727-3738. Medline

Parent JM, Tada E, Fike JR, Lowenstein DH (1999) Inhibition of dentate granule cell neurogenesis with brain irradiation does not prevent seizureinduced mossy fiber synaptic reorganization in the rat. J Neurosci 19: 4508-4519. Medline

Parent JM, Elliott RC, Pleasure SJ, Barbaro NM, Lowenstein DH (2006) Aberrant seizure-induced neurogenesis in experimental temporal lobe epilepsy. Ann Neurol 59:81-91. CrossRef Medline

Patrylo PR, Schweitzer JS, Dudek FE (1999) Abnormal responses to perforant path stimulation in the dentate gyrus of slices from rats with kainate-induced epilepsy and mossy fiber reorganization. Epilepsy Res 36:31-42. CrossRef Medline

Peret A, Christie LA, Ouedraogo DW, Gorlewicz A, Epsztein J, Mulle C, Crépel V (2014) Contribution of aberrant GluK2-containing kainate receptors to chronic seizures in temporal lobe epilepsy. Cell Rep 8:347-354. CrossRef Medline

Represa A, Jorquera I, Le Gal La Salle G, Ben-Ari Y (1993) Epilepsy induced collateral sprouting of hippocampal mossy fibers: does it induce the development of ectopic synapses with granule cell dendrites? Hippocampus 3:257-268. CrossRef Medline

Ribak CE, Shapiro LA (2007) Ultrastructure and synaptic connectivity of cell types in the adult rat dentate gyrus. Prog Brain Res 163:155-166. CrossRef Medline

Ribak CE, Tran PH, Spigelman I, Okazaki MM, Nadler JV (2000) Status epilepticus-induced hilar basal dendrites on rodent granule cells contribute to recurrent excitatory circuitry. J Comp Neurol 428:240-253. CrossRef Medline

Sachidhanandam S, Blanchet C, Jeantet Y, Cho YH, Mulle C (2009) Kainate receptors act as conditional amplifiers of spike transmission at hippocampal mossy fiber synapses. J Neurosci 29:5000-5008. CrossRef Medline

Salin PA, Scanziani M, Malenka RC, Nicoll RA (1996) Distinct short-term plasticity at two excitatory synapses in the hippocampus. Proc Natl Acad Sci U S A 93:13304-13309. CrossRef Medline

Scharfman HE, Sollas AL, Berger RE, Goodman JH (2003) Electrophysiological evidence of monosynaptic excitatory transmission between granule cells after seizure-induced mossy fiber sprouting. J Neurophysiol 90: 2536-2547. CrossRef Medline

Shibley H, Smith BN (2002) Pilocarpine-induced status epilepticus results in mossy fiber sprouting and spontaneous seizures in C57BL/6 and CD-1 mice. Epilepsy Res 49:109-120. CrossRef Medline

Sloviter RS (1987) Decreased hippocampal inhibition and a selective loss of interneurons in experimental epilepsy. Science 235:73-76. CrossRef Medline

Sloviter RS, Zappone CA, Harvey BD, Frotscher M (2006) Kainic acid-induced recurrent mossy fiber innervation of dentate gyrus inhibitory interneurons: possible anatomical substrate of granule cell hyper-inhibition in chronically epileptic rats. J Comp Neurol 494:944-960. CrossRef Medline

Sutula T, He XX, Cavazos J, Scott G (1988) Synaptic reorganization in the hippocampus induced by abnormal functional activity. Science 239: 1147-1150. CrossRef Medline

Sutula T, Koch J, Golarai G, Watanabe Y, McNamara JO (1996) NMDA receptor dependence of kindling and mossy fiber sprouting: evidence that the NMDA receptor regulates patterning of hippocampal circuits in the adult brain. J Neurosci 16:7398-7406. Medline

Tauck DL, Nadler JV (1985) Evidence of functional mossy fiber sprouting in hippocampal formation of kainic acid-treated rats. J Neurosci 5:10161022. Medline

Ting JT, Daigle TL, Chen Q, Feng G (2014) Acute brain slice methods for adult and aging animals: application of targeted patch clamp analysis and optogenetics. Methods Mol Biol 1183:221-242. CrossRef Medline

Toth K, Suares G, Lawrence JJ, Philips-Tansey E, McBain CJ (2000) Differential mechanisms of transmission at three types of mossy fiber synapse. J Neurosci 20:8279-8289. Medline

van Praag H, Schinder AF, Christie BR, Toni N, Palmer TD, Gage FH (2002) 
Functional neurogenesis in the adult hippocampus. Nature 415:10301034. CrossRef Medline

Villasana LE, Kim KN, Westbrook GL, Schnell E (2015) Functional integration of adult-born hippocampal neurons after traumatic brain injury. eNeuro 2:pii:ENEURO.0056-15.2015. CrossRef Medline

Vyleta NP, Borges-Merjane C, Jonas P (2016) Plasticity-dependent, full detonation at hippocampal mossy fiber-CA3 pyramidal neuron synapses. Elife 5:pii:e17977. CrossRef Medline

Walter C, Murphy BL, Pun RY, Spieles-Engemann AL, Danzer SC (2007) Pilocarpine-induced seizures cause selective time-dependent changes to adult-generated hippocampal dentate granule cells. J Neurosci 27:75417552. CrossRef Medline

Weisskopf MG, Nicoll RA (1995) Presynaptic changes during mossy fibre
LTP revealed by NMDA receptor-mediated synaptic responses. Nature 376:256-259. CrossRef Medline

Wong M (2013) Mammalian target of rapamycin (mTOR) pathways in neurological diseases. Biomedical J 36:40-50. CrossRef Medline

Wuarin JP, Dudek FE (1996) Electrographic seizures and new recurrent excitatory circuits in the dentate gyrus of hippocampal slices from kainatetreated epileptic rats. J Neurosci 16:4438-4448. Medline

Wuarin JP, Dudek FE (2001) Excitatory synaptic input to granule cells increases with time after kainate treatment. J Neurophysiol 85:1067-1077. Medline

Zeng LH, Rensing NR, Wong M (2009) The mammalian target of rapamycin signaling pathway mediates epileptogenesis in a model of temporal lobe epilepsy. J Neurosci 29:6964-6972. CrossRef Medline 